\title{
Taxonomy of Pseudomonas Strains Isolated from Tomato Pith Necrosis: Emended Description of Pseudomonas corrugata and Proposal of Three Unnamed Fluorescent Pseudomonas Genomospecies
}

\author{
L. SUTRA, ${ }^{1,2}$ F. SIVERIO,${ }^{3}$ M. M. LOPEZ,${ }^{4}$ G. HUNAULT, ${ }^{2}$ C. BOLLET, ${ }^{5}$ AND L. GARDAN ${ }^{1 *}$ \\ Institut National de la Recherche Agronomique, Station de Pathologie Végétale et Phytobactériologie, Beaucouzé, ${ }^{1}$ \\ Université d'Angers, Faculté des Sciences, Angers, ${ }^{2}$ and Antimicrobiens et Facteurs de Colonisation dans les \\ Pathologies Transmissibles, Faculté de Pharmacie, Marseille, ${ }^{5}$ France; and Instituto Canario de \\ Investigaciones Agrarias, La Laguna, Tenerife, ${ }^{3}$ and Instituto Valenciano \\ de Investigaciones Agrarias, Valencia, ${ }^{4}$ Spain
}

\begin{abstract}
Thirty-three fluorescent Pseudomonas strains isolated from tomato pith necrosis (FPTPN strains) and 89 $P$ seudomonas corrugata strains were studied by numerical taxonomy. In the dendrogram of distances, the $P$. corrugata strains constituted a single phenon (phenon 1), whereas 17 of the 33 FPTPN strains clustered in a separate phenon (phenon 2). The other 16 FPTPN strains were included in phena consisting of well-characterized fluorescent Pseudomonas species or were isolated phenotypes. Phena 1 and 2 were distinguished by fluorescence on King B medium, accumulation of poly- $\beta$-hydroxybutyrate, production of levan, and assimilation of sorbitol. DNA-DNA hybridization showed that $P$. corrugata is a true genomic species (66 to $100 \%$ DNA relatedness) and that the FPTPN strains of phenon 2 were divided into three genomic groups. Genomic groups 1 and 2 were not distinct from each other phenotypically, and genomic group 3 could be distinguished from genomic groups 1 and 2 only on the basis of assimilation of citraconate and laevulinate. Genomic groups 1 and 2 are related to $P$. corrugata (40 to 55\% DNA relatedness), whereas genomic group 3 is less closely related to $P$. corrugata (20 to $23 \%$ DNA relatedness). The lipopolysaccharide patterns on electrophoresis gels and fatty acid profiles of strains belonging to genomic groups 1 through 3 are different from each other and from the lipopolysaccharide patterns and fatty acid profiles of $P$. corrugata. However, cross-reactions were observed between $P$. corrugata and the FPTPN strain genomic groups, indicating that there are common epitopes of the lipopolysaccharides. The three FPTPN strain genomic groups were not named as species but were designated Pseudomonas genomospecies FP1, FP2, and FP3.
\end{abstract}

Pseudomonas corrugata Roberts and Scarlett 1981 was first described by Scarlett et al. (35) as the causal agent of tomato pith necrosis. $P$. corrugata has been isolated all over the world and causes pith necrosis mainly in tomato $(2,7,8,15,21,23$, $25,32,35$ ), but also in pepper (25) and chrysanthemum (14). This bacterium has also been identified in symptomless alfalfa plants (26), soil (37), and rice grains (45). Several authors have indicated that it is a ubiquitous bacterium with a wide range of host plants, a common characteristic of many opportunistic fluorescent pseudomonads $(26,35,38)$.

In the original description based on a limited number of phenotypic and pathogenic characteristics (35), $P$. corrugata was considered a nonfluorescent Pseudomonas species that accumulates poly- $\beta$-hydroxybutyrate (PHB). Consequently, Palleroni (31) included $P$. corrugata in section $\mathrm{V}$ of the genus Pseudomonas among the nonfluorescent bacteria now classified in the genera Pseudomonas, Burkholderia, and Acidovorax. On the basis of DNA-rRNA hybridization data, De Vos et al. (12) included $P$. comugata in the Pseudomonas fluorescens rRNA group, among the fluorescent pseudomonads. A similar conclusion was reached by Stead (42), who grouped plantpathogenic pseudomonads and other species of pseudomonads on the basis of their fatty acid profiles and placed $P$. corrugata

\footnotetext{
* Corresponding author. Mailing address: Institut National de la Recherche Agronomique, Station de Pathologie Végétale et Phytobactériologie, BP 47, 42 rue Georges Morel, 49071 Beaucouzé Cedex, France. Phone: (33) 02412257 29. Fax: (33) 02412257 05. E-mail: gardan@angers.inra.fr.
}

in group 1, which contained six subgroups. One of these subgroups, subgroup 1a, corresponded to the fluorescent pseudomonads, and subgroup 1 b corresponded to $P$. corrugata (it was the only member of this subgroup). Hu et al. (19), who performed a numerical analysis of biochemical and nutritional properties, recognized $P$. corrugata as a distinct species of the genus Pseudomonas. Young et al. (48) included $P$. corrugata in the fluorescent group, but considered it to be anomalous, because it is nonfluorescent and PHB positive. Recent studies performed with a collection of $P$. corrugata strains from different hosts and countries demonstrated that there is a great deal of heterogeneity in the biochemical and serological characteristics of these organisms $(38,39)$ and in their fatty acid profiles (40).

Several fluorescent pseudomonads have also been identified in different countries as causal agents of tomato pith necrosis; these organisms include Pseudomonas cichorii in New Zealand (47) and unidentified fluorescent pseudomonads in Greece, Canada, and Italy $(3,6,13)$. The relatively frequent isolation of fluorescent Pseudomonas strains from tomato pith necrosis (FPTPN strains) in France and Spain prompted us to study the characteristics of these isolates in comparison with the characteristics of $P$. corrugata.

The aims of this work were (i) to improve our knowledge of the phenotypic diversity of $P$. corrugata strains, (ii) to compare $P$. comugata strains with FPTPN strains, and (iii) to study the genomic homology among strains of $P$. corrugata and FPTPN strains and between the two groups. To do this, we used a polyphasic approach, which included a numerical taxonomy 
TABLE 1. Distribution of strains among the phena and isolated phenotypes

\begin{tabular}{|c|c|c|c|}
\hline Phenon or group & $\begin{array}{l}\text { Subphenon or } \\
\text { subgroup }\end{array}$ & No. of strains & Strain(s) \\
\hline \multirow[t]{3}{*}{1} & 1a & 63 & $\begin{array}{l}\text { Pseudomonas corrugata CFBP } 2431^{\mathrm{T}} \text {; Pseudomonas corrugata strains isolated from } \\
\text { tomato ( } 59 \text { strains), pepper ( } 1 \text { strain), and lucerne ( } 2 \text { strains) }\end{array}$ \\
\hline & $1 \mathrm{~b}$ & 20 & $\begin{array}{l}\text { Pseudomonas corrugata strains isolated from tomato (18 strains) and pepper (1 } \\
\text { strain); FPTPN strain CFBP } 10552\end{array}$ \\
\hline & & 6 & $\begin{array}{l}\text { Isolated phenotypes: Pseudomonas comugata CFBP 10143, CFBP 10560, CFBP } \\
\text { 10902, CFBP 10903, CFBP 10930, and CFBP } 10937\end{array}$ \\
\hline \multirow[t]{4}{*}{2} & $2 \mathrm{a}$ & 8 & $\begin{array}{l}\text { FPTPN strains CFBP 10435, CFBP 10437, CFBP 10529, CFBP 10604, CFBP } \\
\text { 10605, CFBP 10934, and CFBP 11062; Pseudomonas corrugata CFBP } 10436\end{array}$ \\
\hline & $2 b$ & 6 & $\begin{array}{l}\text { FPTPN strains CFBP 10530, CFBP 10531, CFBP 10533, CFBP 10551, CFBP } \\
\text { 10567, and CFBP } 10591\end{array}$ \\
\hline & $2 \mathrm{c}$ & 3 & FPTPN strains CFBP 10524, CFBP 10569, and CFBP 10583 \\
\hline & & 1 & Isolated phenotype: FPTPN strain CFBP 10535 \\
\hline 3 & & 2 & $\begin{array}{l}\text { Pseudomonas fluorescens biotype II strain CFBP 2125; Pseudomonas fluorescens } \\
\text { biotype IV strain CFBP } 2129\end{array}$ \\
\hline 4 & & 10 & $\begin{array}{l}\text { Pseudomonas fuscovaginae CFBP } 2065^{\mathrm{T}} \text {, CFBP 2801, CFBP 2802, CFBP 2803, } \\
\text { CFBP 2805, CFBP 2808, CFBP 3081, CFBP 3082, CFBP 3083, and CFBP } 3084\end{array}$ \\
\hline 5 & & 14 & $\begin{array}{l}\text { Pseudomonas marginalis pv. marginalis CFBP } 10051 \text {, CFBP } 10053 \text {, CFBP } 10054 \text {, } \\
\text { CFBP 10061, CFBP 10068, and CFBP 1538; Pseudomonas marginalis pv. } \\
\text { pastinacae CFBP } 2038^{\mathrm{T}} \text {; Pseudomonas marginalis pv. alfalfae CFBP } 2039^{\mathrm{T}} \text {; } \\
\text { Pseudomonas fluorescens biovar I strain CFBP } 2123 \text {; FPTPN strains CFBP } \\
\text { 10537, CFBP 10539, CFBP 10549, CFBP 10562, and CFBP } 10563\end{array}$ \\
\hline 6 & & 11 & $\begin{array}{l}\text { Pseudomonas sp. strain CFBP 2022; Pseudomonas fluorescens biovar I strain } \\
\text { CFBP 2102 } \text {; Pseudomonas tolaasii CFBP 2068 }{ }^{\mathrm{T}} \text {, CFBP 2810, CFBP 10046, } \\
\text { CFBP 10047, CFBP 10071, CFBP 10074, CFBP 10075, and CFBP 10076; } \\
\text { FPTPN strain CFBP } 10582\end{array}$ \\
\hline 7 & & 3 & $\begin{array}{l}\text { Pseudomonas asplenii CFBP 3279; “Pseudomonas blatchfordae” CFBP 3280; } \\
\text { Pseudomonas flectens CFBP 3281 }\end{array}$ \\
\hline 8 & & 3 & $\begin{array}{l}\text { Pseudomonas aeruginosa } \text { CFBP } 2466^{\mathrm{T}} \text {; FPTPN strains CFBP } 10601 \text { and CFBP } \\
10602\end{array}$ \\
\hline 9 & & 2 & Pseudomonas chlororaphis CFBP $2132^{\mathrm{T}}$; Pseudomonas aureofaciens CFBP $2133^{\mathrm{T}}$ \\
\hline 10 & & 2 & Pseudomonas putida CFBP $2066^{\mathrm{T}}$ and CFBP 3142.1 \\
\hline 11 & & 11 & $\begin{array}{l}\text { Pseudomonas cichorii CFBP } 2101^{\mathrm{T}} \text {, CFBP } 1149 \text {, CFBP } 1474 \text {, CFBP } 1477 \text {, CFBP } \\
\text { 11417, CFBP } 11420 \text {, CFBP } 11424 \text {, CFBP 11431, CFBP 11434, CFBP 11435, } \\
\text { and CFBP } 11443\end{array}$ \\
\hline 12 & & 2 & FPTPN strains CFBP 10960 and CFBP 10962 \\
\hline 13 & & 2 & $\begin{array}{l}\text { Burkholderia gladioli pv. allicola CFBP } 2422^{\mathrm{T}} \text { and Burkholderia gladioli pv. gladioli } \\
\text { CFBP } 2427^{\mathrm{T}}\end{array}$ \\
\hline & & 2 & Acidovorax avenae subsp. avenae CFBP $2425^{\mathrm{T}}$ and CFBP 2426 \\
\hline Isolated phenotypes & & 25 & 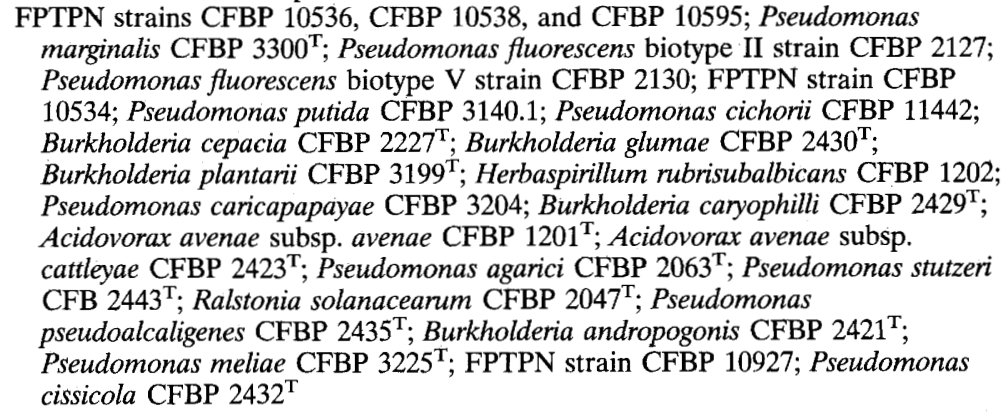 \\
\hline
\end{tabular}

analysis based on data from phenotypic tests, DNA-DNA hybridizations, fatty acid profiles, lipopolysaccharide (LPS) patterns in electrophoresis gels, serology, and pathogenicity tests.

\section{MATERIALS AND METHODS}

Bacterial strains. A total of 196 strains were studied (Table 1). The first set of strains included 33 FPTPN strains isolated from 1980 to 1990 in France (24 strains), Spain ( 5 strains), Switzerland ( 2 strains), and Canada (2 strains). The two strains from Canada (CFBP 10435 and CFBP 10437) were previously described as novel agents of tomato stem necrosis (13). The strains in the second set of strains ( $89 P$. corrugata strains) were isolated from tomato (85 strains) pepper ( 2 strains), and lucerne ( 2 strains) in the following 11 countries: Spain (31 strains), France (17 strains), New Zealand (9 strains), United Kingdom (8 strains), United States ( 8 strains), Italy (4 strains), Switzerland (4 strains), Japan (3 strains), Germany (2 strains), Sweden ( 2 strains), and Canada (1 strain). The third set of strains included 74 type strains or well-characterized strains of fluorescent and nonfluorescent Pseudomonas, Acidovorax, Burkholderia, Herbaspirillum, and Ralstonia species, used as reference strains for numerical taxonomy and DNA-DNA hybridizations.

All of the bacteria were cultured routinely on YBGA (yeast extract, $7 \mathrm{~g}$; Bacto Peptone [Difco], $7 \mathrm{~g}$; glucose, $7 \mathrm{~g}$; agar, $15 \mathrm{~g}$; distilled water, $1,000 \mathrm{ml} ; \mathrm{pH} 7.2$ ) and incubated at $25^{\circ} \mathrm{C}$.

Biochemical and physiological tests. The presence of oxidase, gelatinase, and arginine dihydrolase activities, production of fluorescent pigment on King B medium, levan formation, acid production from sucrose, sorbitol, erythritol, and mannitol, reduction of nitrates, hydrolysis of Tween 80 and esculin, and the hypersensitivity reaction on tobacco leaves were tested as described by Leliott et al. (24). Pectolytic activity was tested by using the method of Prunier and Kaiser (33) and Hildebrand (17). Utilization of lactate, L-(+)-tartrate, and D-(-)tartrate was tested on the basal medium of Ayers et al. (4) supplemented with $0.1 \%$ (wt/vol) organic acid sodium salts. The presence of DNase was tested on 
DNA agar (Diagnostic Pasteur, Marnes la Coquette, France). Assimilation of 49 carbohydrates, 49 organic acids, and 49 amino acids was studied by using API 50CH, API 50AO, and API 50AA strips (BioMérieux, La Balme les Grottes, France), respectively. The accumulation of granules of PHB was tested by the method of Ostle and Holt (29) by using Nile blue A; Ralstonia solanacearum CFBP $2047^{\mathrm{T}}$ was used as a positive control. Flagella were stained by the method of Rhodes (34).

Numerical taxonomy. A total of 167 characteristics were included in the numerical taxonomy analysis. A distance matrix was calculated by using the Jaccard coefficient (41). Cluster analysis was done by using the unweighted pair group method with averages. At a given distance level and for the different phena, the amount of information for each test was measured by calculating the diagnostic ability coefficient to determine the discriminating biochemical characteristics of the strains (10).

DNA extraction and purification. Extraction and purification of DNA were performed by using previously described methods (5).

DNA-DNA hybridization. Native DNAs were labeled in vitro by nick translation with tritium-labeled nucleotides (Amersham International, Amersham, England). The S1 nuclease-trichloroacetic acid method used for hybridization has been described previously $(9,16)$. The reassociation temperature was $70^{\circ} \mathrm{C}$ DNA-DNA hybridization tests were carried out by using labeled DNAs from $P$. corrugata CFBP $2431^{\mathrm{T}}$ and from three FPTPN strains (CFBP 10529, CFBP 10530 , and CFBP 10569). The strains used in DNA-DNA hybridizations are listed in Tables 4 and 5. DNA-DNA hybridization tests were repeated at least twice.

Thermal stability of reassociated DNA. The temperature at which $50 \%$ of reassociated DNA became hydrolyzable by nuclease $\mathrm{S} 1\left(T_{m}\right)$ was determined by using the method of Crosa et al. (9). The $T_{m}$ was determined only if the level of DNA-DNA hybridization was between 65 and $70 \%$.

DNA base composition. The guanine-plus-cytosine $(\mathrm{G}+\mathrm{C})$ contents of $P$. corrugata CFBP $2431^{\mathrm{T}}$ and FPTPN strains CFBP 10529, CFBP 10530, and CFBP 10569 were determined by the thermal denaturation temperature method (27) and were calculated by using the equation of Owen and Lapage (30).

Serological techniques. Six rabbit antisera were prepared with bacterial somatic antigens and were used as described by Siverio et al. (39). Three antiser were raised against $P$. comugata CFBP $2431^{\mathrm{T}}$, CFBP 10147 , and CFBP 10148 , and the characteristics of these antisera have been studied previously (39). Three other antisera were prepared against FPTPN strains CFBP 10529, CFBP 10530 and CFBP 10569

An indirect enzyme-linked immunosorbent assay (ELISA-I) was used to determine serological relationships among $P$. comigata and FPTPN strains. The technique used has been described by Siverio et al. (39). Two replicates consisting of four wells in two different plates were coated with each bacterial isolate Standard positive and negative controls were included in each plate to make comparisons between plates feasible. The positive control was a mixture of suspensions $\left(10^{7} \mathrm{CFU} / \mathrm{ml}\right.$ in carbonate buffer, $\mathrm{pH}$ 9.6) of the six strains homologous to the six antisera used. The control wells were subsequently treated with a mixture of the six antisera at working dilutions $(1: 25,000$ for the serum against strain CFBP $2431^{\mathrm{T}} ; 1: 8,000$ for the serum against strain CFBP 10147; 1:5,000 for the serum against strain CFBP 10148; and 1:10,000 for the sera against strains CFBP 10529, CFBP 10530, and CFBP 10569). A reaction was considered positive when the absorbance was twice that of the negative control in each plate.

LPS patterns. Preparation of whole-cell bacterial lysates, proteinase K hydrolysis, polyacrylamide gel electrophoresis, and silver staining were performed with 15 P. corrugata strains and 18 FPTPN strains by the methods of Alarcon et al. (1), Hitchcock and Brown (18), Laemmli (22), and Tsai and Frasch (44), respectively, as described in detail elsewhere (39). LPS profiles were determined at least twice for each strain analyzed.

FAME profiles. The fatty acid methyl ester (FAME) profiles of $16 P$. comugato strains and 17 FPTPN strains were determined by the standardized technique described by Miller and Berger (28) by using the Microbial Identification System (Hewlett-Packard model 5898 instrument) controlled with the Microbial Identification System software (MIDI; Microbial ID, Inc., Newark, Del.). The unweighted pair group method with averages was used to perform a cluster analysis of the FAME profiles.

Pathogenicity tests. All of the plants used were grown in a greenhouse. In the first experiment, the pathogenicity of a some of $30 \mathrm{P}$. corrugata strains and 17 FPTPN strains for tomato (Lycopersicon esculentum cv. INRA Montfavet 63.4) was tested by using 2-month-old plants (five plants per bacterial strain). Bacterial suspensions (about $10^{7} \mathrm{CFU} / \mathrm{ml}$ ) in sterile water were injected into the stems with a hypodermic needle at two points (about $30 \mathrm{~cm}$ and $1 \mathrm{~m}$ above the soil). Symptoms were recorded for up to 8 weeks after inoculation; each plant was longitudinally cut, and the length of the pith necrosis was measured.

In the second experiment, 1-month-old plants of tomato, tobacco (Nicotiana tabacum), pepper (Capsicum annuum), bean (Phaseolus vulgaris), cauliflower (Brassica oleracea var. botrytis), melon (Cucumis sativus), and zucchini (Cucurbita pepo) were used. One inoculation (about $10 \mathrm{~cm}$ above the soil) was performed as described above with $P$. corrugata CFBP $2431^{\mathrm{T}}$ and CFBP 10148 and with FPTPN strains CFBP 10529, CFBP 10530, CFBP 10569, and CFBP 10934. After inoculation, the plants were kept for 3 days at a relative humidity of $100 \%$ and then at 20 to $25^{\circ} \mathrm{C}$ at a relative humidity of $70 \%$. Observations were made for up to 4 weeks after inoculation; every plant was longitudinally cut, and the length of the pith necrosis was measured. For each plant species tested, reisolation of bacteria was done on YBGA or on King B agar. In each experiment, 5 to 10 control plants were inoculated with sterile distilled water.

\section{RESULTS}

Numerical analysis of phenotypic characteristics. A dendrogram displaying the distance relationships among the 196 strains included in this study is shown in Fig. 1. At a distance of $0.2025,14$ phena and 25 isolated phenotypes were observed. The distribution of strains in the different phena (clusters with at least two strains) and isolated phenotypes is shown in Table 1. Six major phena containing more than 10 strains (phena 1, 2, 4 through 6 , and 11) were observed.

Phenon 1 contained all of the $89 P$. corrugata strains except strain CFBP 10436 and included type strain CFBP 2431 and FPTPN strain CFBP 10552.

Phenon 2 included 17 FPTPN strains and one $P$. corrugata strain, CFBP 10436.

Phenon 4 contained 10 Pseudomonas fuscovaginae strains, including type strain CFBP 2065.

Phenon 5 contained 14 fluorescent oxidase-positive Pseudomonas strains: 8 strains of Pseudomonas marginalis pathovars, including type strain CFBP $3300, P$. fluorescens biotype I strain CFBP 2123, and FPTPN strains CFBP 10537, CFBP 10539, CFBP 10549, CFBP 10562, and CFBP 10563.

Phenon 6 contained the following 11 fluorescent oxidasepositive Pseudomonas strains: eight Pseudomonas tolaasii strains, including type strain CFBP 2068, P. fluorescens biotype I strain CFBP $2102^{\mathrm{T}}, P$. fluorescens CFBP 2022, and FPTPN strain CFBP 10582.

Phenon 11 contained $11 \mathrm{P}$. cichorii strains including type strain CFBP 2101.

Eight minor phena (phena 3, 7 through 10, and 12 through 14) each contained two or three strains. Phenon 3 contained two strains of $P$. fluorescens biotypes II and IV, phenon 8 contained Pseudomonas aeruginosa CFBP $2466^{\mathrm{T}}$ and FPTPN strains CFBP 10601 and CFBP 10602, phenon 10 contained Pseudomonas putida CFBP $2066^{\mathrm{T}}$ and CFBP 3142.1 , and phenon 12 contained FPTPN strains CFBP 10960 and CFBP 10962. The other minor phena (phena 7, 9, 13, and 14) included the type strains of phytopathogenic Pseudomonas, Burkholderia, or Acidovorax species (Table 1).

Of the 25 unclustered phenotypes at a distance of $0.2025,12$ corresponded to the type strains of fluorescent or nonfluorescent Pseudomonas, Acidovorax, Burkholderia, Herbaspirillum, and Ralstonia species.

The 33 FPTPN strains were distributed as follows: 1 strain in phenon 1,17 strains in phenon 2, 5 strains in phenon 5,1 strain in phenon 6,2 strains in phenon 8 , and 2 strains in phenon 12 , which is closely related to $P$. cichorii (phenon 11). Strains CFBP 10534, CFBP 10536, CFBP 10538, CFBP 10595, and CFBP 10937 appeared as isolated phenotypes (Table 1).

Biochemical and physiological characteristics that differentiate the six major phena, phena 1,2, 4 through 6 , and 11 , are shown in Table 2. The strains that clustered in phena 1 and 2, which were isolated from plants with tomato pith necrosis and are $P$. corrugata and FPTPN strains, respectively, are closely related phenotypically and could be distinguished only by the following four biochemical tests: production of fluorescent pigment on King B medium, accumulation of PHB, levan formation, and assimilation of sorbitol.

At a distance of $0.1755, P$. corrugata phenon 1 was divided into two subphena, subphena $1 \mathrm{a}$ and $1 \mathrm{~b}$, which included 83 $(93.9 \%)$ of the 89 strains, and six isolated phenotypes. The strains of subphena $1 \mathrm{a}$ and $1 \mathrm{~b}$ can be distinguished by the 


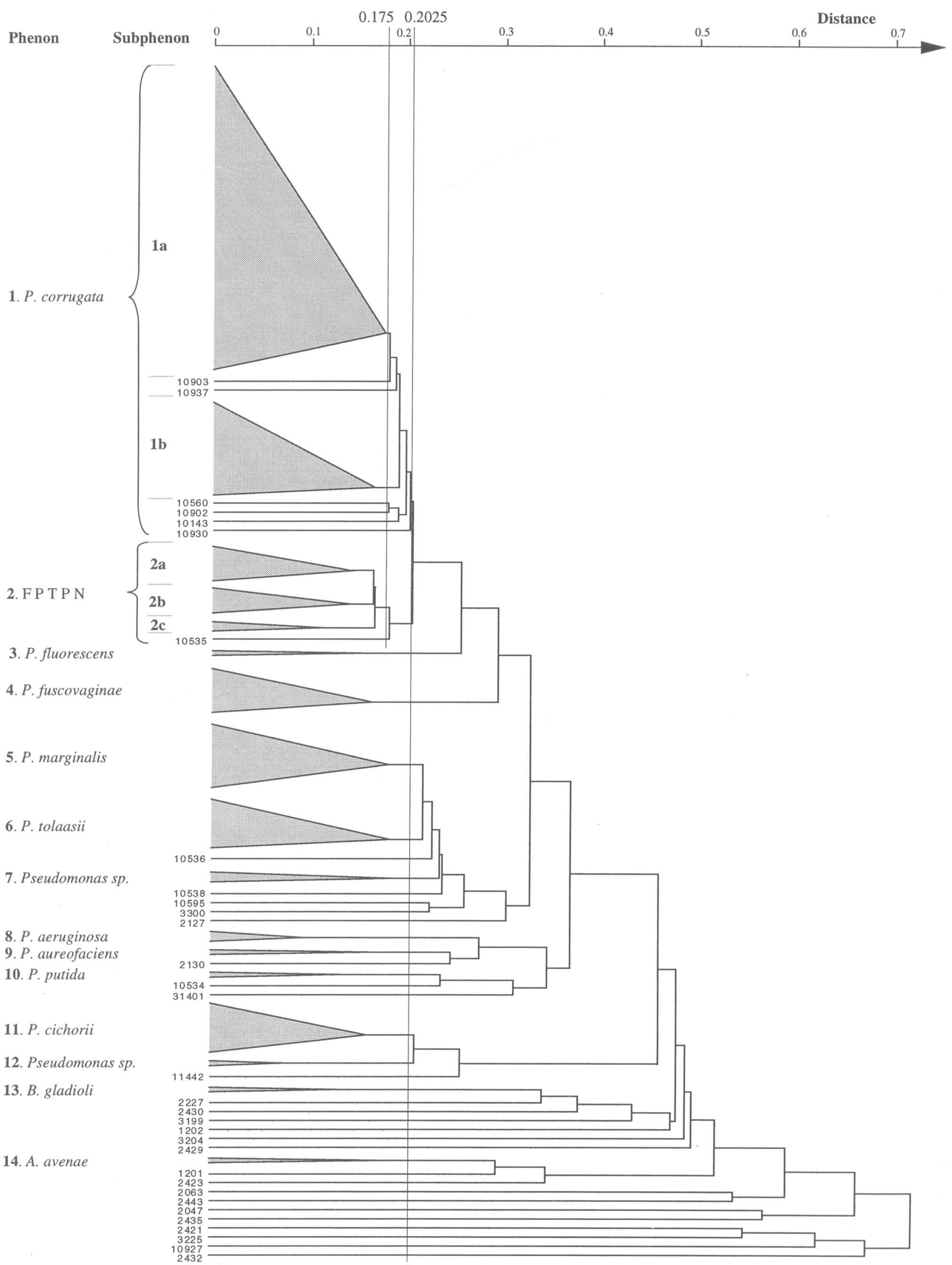

FIG. 1. Dendrogram of phenotypic distances for 196 strains. The number of strains in each phenon is indicated in Table 1. 
TABLE 2. Phenotypic characteristics that differentiate phena $1,2,4$ through 6 , and 11

\begin{tabular}{|c|c|c|c|c|c|c|}
\hline Characteristic & 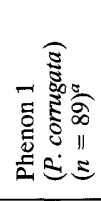 & 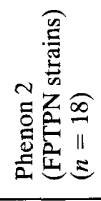 & 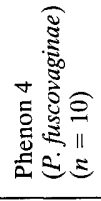 & 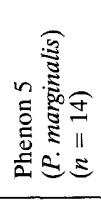 & 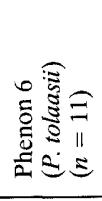 & 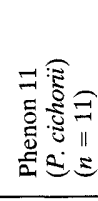 \\
\hline Fluorescence on King B medium ${ }^{b}$ & $--^{c}$ & + & + & + & + & $\mathrm{d}(63)^{b}$ \\
\hline Levan production ${ }^{b}$ & - & + & - & $\mathrm{d}(57)^{b}$ & $\mathrm{~d}(18)^{b}$ & - \\
\hline Arginine dihydrolase & $\mathrm{d}(77)$ & + & + & + & + & - \\
\hline Gelatin hydrolysis & $\mathrm{d}(60)$ & $\mathrm{d}(55)$ & $\mathrm{d}(50)$ & $\mathrm{d}(71)$ & + & - \\
\hline Nitrate reduction ${ }^{d}$ & + & + & - & + & - & - \\
\hline Esculin hydrolysis & - & - & - & $\mathrm{d}(27)$ & - & + \\
\hline Hypersensitivity reaction & $\mathrm{d}(19)$ & - & - & - & - & + \\
\hline \multicolumn{7}{|c|}{ Utilization of carbohydrates and polyalcohols } \\
\hline Sucrose & + & + & - & $d(78)$ & $\mathrm{d}(28)$ & - \\
\hline Trehalose & + & + & + & + & + & - \\
\hline L-Arabinose & + & + & + & + & $\mathrm{d}(36)$ & + \\
\hline D-Xylose & + & + & + & + & $\mathrm{d}(34)$ & + \\
\hline $\mathrm{N}$-Acetylglucosamine & + & $\mathrm{d}(66)$ & - & + & + & - \\
\hline Glucosamine $^{d}$ & + & + & + & + & + & - \\
\hline Sorbitol $^{b}$ & - & + & - & + & + & $\mathrm{d}(18)^{b}$ \\
\hline Adonitol & - & - & - & $\mathrm{d}(71)$ & + & - \\
\hline Erythritol & - & - & - & $\mathrm{d}(78)$ & + & - \\
\hline Xylitol & - & - & - & $\mathrm{d}(78)$ & + & - \\
\hline Inositol $^{d}$ & + & + & - & + & + & + \\
\hline L-Arabitol & - & - & - & $\mathrm{d}(71)$ & + & - \\
\hline \multicolumn{7}{|l|}{ Utilization of organic salts } \\
\hline L-(+)-Tartrate & - & - & - & $\mathrm{d}(28)$ & - & + \\
\hline 2-Aminobenzoate ${ }^{d}$ & - & - & + & + & + & - \\
\hline meso-Tartrate & $\mathrm{d}(22)$ & - & + & $\mathrm{d}(78)$ & + & + \\
\hline$n$-Valerate & + & + & $\mathrm{d}(50)$ & + & + & - \\
\hline Isovalerate & $\mathrm{d}(79)$ & $\mathrm{d}(83)$ & - & + & $\mathrm{d}(27)$ & - \\
\hline Isobutyrate & $d(66)$ & + & $\mathrm{d}(80)$ & + & + & - \\
\hline 2-Ketogluconate & $\mathrm{d}(33)$ & $\mathrm{d}(72)$ & - & + & + & $d(36)$ \\
\hline Mesaconate $^{d}$ & - & - & - & + & + & - \\
\hline Itaconate & - & $\mathrm{d}(38)$ & - & + & + & - \\
\hline Citraconate & $\mathrm{d}(15)$ & $d(16)$ & + & + & $\mathrm{d}(81)$ & - \\
\hline Laevulinate & - & $\mathrm{d}(27)$ & - & $\mathrm{d}(85)$ & $\mathrm{d}(23)$ & - \\
\hline \multicolumn{7}{|c|}{ Utilization of amino acids and nitrogenous compounds } \\
\hline L-Tryptophan ${ }^{d}$ & - & - & - & + & + & - \\
\hline L-Valine ${ }^{d}$ & + & + & + & + & + & - \\
\hline L-Leucine ${ }^{d}$ & + & + & + & + & + & - \\
\hline L-Phenylalanine ${ }^{d}$ & + & + & + & + & + & - \\
\hline L-Citruline & - & - & + & $\mathrm{d}(78)$ & $\mathrm{d}(45)$ & - \\
\hline L-Alanine ${ }^{d}$ & + & + & + & + & + & - \\
\hline L-Isoleucine $\mathrm{e}^{d}$ & + & + & + & + & + & - \\
\hline Histamine & $\mathrm{d}(26)$ & - & - & - & $\mathrm{d}(18)$ & - \\
\hline Spermine $^{d}$ & + & + & - & + & + & - \\
\hline Trigonelline & + & $\mathrm{d}(77)$ & $\mathrm{d}(80)$ & + & - & + \\
\hline DL-Kynurenine & - & - & - & + & $\mathrm{d}(81)$ & - \\
\hline Ethanolamine & $\mathrm{d}(77)$ & + & + & + & $\mathrm{d}(72)$ & - \\
\hline Amylamine & $\mathrm{d}(13)$ & $\mathrm{d}(44)$ & - & $\mathrm{d}(57)$ & - & - \\
\hline DL-5-Aminovalerate & + & + & - & + & $\mathrm{d}(81)$ & $\mathrm{d}(45)$ \\
\hline
\end{tabular}

${ }^{a} n$ is the number of strains in the phenon.

${ }^{b}$ Characteristic that differentiates phena 1 and 2.

$c-$, negative;,+ 90 to $100 \%$ of the strains are positive; $d, 11$ to $89 \%$ of the strains are positive. The numbers in parentheses are the percentages of positive strains. ${ }^{d}$ Characteristic that clearly differentiates the six phena.

following characteristics: assimilation of meso-tartrate, isobyturate, and histamine (Table 3 ).

At a distance of 0.150 , phenon 2 (FPTPN strains) was divided into three subphena, subphena $2 \mathrm{a}, 2 \mathrm{~b}$, and $2 \mathrm{c}$, and one isolated phenotype (strain CFBP 10535). Subphena $2 a$ and $2 b$ could not be clearly differentiated on the basis of the 167 biochemical tests used. In contrast, strains in subphenon $2 \mathrm{c}$ assimilated citraconate and laevulinate, whereas strains in subphena $2 \mathrm{a}$ and $2 \mathrm{~b}$ did not.

DNA relatedness. The results of DNA-DNA hybridizations are shown in Table 4 . A total of $14 P$. corrugata strains in phenon 1 (10 strains in subphenon $1 \mathrm{a}$ and 4 strains in subphenon $1 b)$ were selected for the DNA-DNA hybridization experiments. These strains demonstrated 66 to $100 \%$ DNA related- 
TABLE 3. Phenotypic characteristics that differentiate phenon 1 ( $P$. corrugata) and phenon 2 (FPTPN strains)

\begin{tabular}{|c|c|c|c|c|c|c|c|c|c|c|}
\hline \multirow{2}{*}{ Taxon } & \multirow{2}{*}{$\begin{array}{l}\text { No. of } \\
\text { strains }\end{array}$} & \multirow{2}{*}{$\begin{array}{l}\text { Fluores- } \\
\text { cence }\end{array}$} & \multirow{2}{*}{$\begin{array}{c}\text { Levan } \\
\text { production }\end{array}$} & \multicolumn{7}{|c|}{ Utilization of: } \\
\hline & & & & Sorbitol & meso-Tartrate & Isobutyrate & 2-Ketogluconate & Citraconate & DL-Glycerate & Histamin \\
\hline Phenon 1 & 89 & $-{ }^{a}$ & - & - & $d(22)$ & $d(66)$ & $\mathrm{d}(33)$ & $\mathrm{d}(15)$ & $\mathrm{d}(41)$ & $\mathrm{d}(26)$ \\
\hline Subphenon 1a & 63 & - & - & - & - & + & $\mathrm{d}(14)$ & - & $\mathrm{d}(25)$ & - \\
\hline Subphenon $1 \mathrm{~b}$ & 20 & - & $\mathrm{d}(20)$ & - & + & - & + & $\mathrm{d}(60)$ & + & + \\
\hline Isolated phenotypes & 6 & & & & & & & & & \\
\hline CFBP 10143 & & - & - & - & - & - & - & - & + & - \\
\hline CFBP 10560 & & - & - & - & - & - & + & - & - & - \\
\hline CFBP 10902 & & - & - & - & - & - & - & - & + & - \\
\hline CFBP 10903 & & - & - & - & - & + & - & - & - & - \\
\hline CFBP 10930 & & - & + & - & - & - & - & - & + & - \\
\hline CFBP 10937 & & - & - & - & - & + & - & - & - & - \\
\hline Phenon 2 & 18 & + & + & + & - & + & $\mathrm{d}(70)$ & $\mathrm{d}(17)$ & + & - \\
\hline
\end{tabular}

${ }^{a}-$, negative; + , positive; $\mathrm{d}$, variable. The values in parentheses are percentages of positive strains.

ness to $P$. corrugata CFBP $2431^{\mathrm{T}}$ (average, $86.3 \%$; standard deviation, $14.9 \%$ ). For the strain pairs that demonstrated the lowest DNA relatedness values (66 to $69 \%)$, the $\Delta T_{m}$ values ranged from 2 to $3.5^{\circ} \mathrm{C}\left(\Delta T_{m}\right.$ is the difference between the $T_{m}$ of a homoduplex and the $T_{m}$ of a heteroduplex). Strain CFBP 10436 , which was a member of subphenon $2 a$, was $92 \%$ related to $P$. corrugata CFBP $2431^{\mathrm{T}}$. Thus, all 15 strains examined are considered members of a single DNA hybridization group.

The 18 FPTPN strains included in phenon 2 (17 strains) and in phenon 1 (strain CFBP 10552) were 20 to $55 \%$ related to the $P$. comugata type strain. These strains constituted three different DNA hybridization groups (Table 4). DNA hybridization group 1 contained nine FPTPN strains which were 67 to $100 \%$ related to strain CFBP 10529 (average level of relatedness, $86.8 \%$; standard deviation, $13.0 \%$ ); DNA hybridization group 2 contained six strains which were 89 to $100 \%$ related to strain CFBP 10530 (average level of relatedness, 95.3\%; standard deviation, $4.5 \%$ ); and DNA hybridization group 3 contained three strains which were 86 to $100 \%$ related to strain CFBP 10569 (average level of relatedness, 93.0\%; standard deviation, $7.0 \%$ ) (Table 4). Most DNA hybridization group 1 and 2 strains clustered in subphena $2 \mathrm{a}$ and $2 \mathrm{~b}$; the one exception was strain CFBP 10552, which was in subphenon 1a. The DNA hybridization group 3 strains were included in subphenon $2 \mathrm{c}$.

The levels of hybridization between labeled DNA from $P$. corrugata CFBP $2431^{\mathrm{T}}$ and DNAs from FPTPN strains belonging to DNA hybridization groups 1 and 2 on the one hand and between labeled DNAs from strains CFBP 10529 (DNA hybridization group 1) and CFBP 10530 (DNA hybridization group 2) and DNAs from $P$. corrugata strains on the other hand varied from 40 to $55 \%$. In contrast, the levels of hybridization between labeled DNA from $P$. corrugata CFBP $2431^{\mathrm{T}}$ and DNAs from strains belonging to DNA hybridization group 3 ranged from 20 to $23 \%$ (Table 4 ).

The levels of relatedness between the DNAs of $P$. corrugata CFBP $2431^{\mathrm{T}}$ and FPTPN strains CFBP 10529, CFBP 10530 , and CFBP 10569 and the DNAs of most type strains of fluorescent phytopathogenic or saprophytic oxidase-positive Pseudomonas species ranged from 15 to 28,12 to 33,14 to 36 , and 10 to $48 \%$, respectively; the one exception was the levels of reassociation with Pseudomonas flectens CFBP $3281^{\mathrm{T}}$, which were less than $2 \%$ (Table 5). The levels of relatedness between the DNAs of $P$. corrugata CFBP $2431^{\mathrm{T}}$ and FPTPN strains CFBP 10529, CFBP 10530, and CFBP 10569 and the DNAs of the type strains of fluorescent oxidase-negative Pseudomonas species varied from 8 to $19 \%$. Most levels of DNA relatedness with reference strains of nonfluorescent Pseudomonas, Ac- idovorax, Burkholderia, Herbaspirillum, and Ralstonia species were less than 5\%; the one exception was the levels of DNA relatedness with Pseudomonas alcaligenes, which ranged from 2 to $12 \%$ (Table 5).

DNA base composition. $P$. corrugata CFBP $2431^{\mathrm{T}}$ had a DNA $\mathrm{G}+\mathrm{C}$ content of $59.6 \mathrm{~mol} \%$. The $\mathrm{G}+\mathrm{C}$ contents of FPTPN strains CFBP 10529, CFBP 10530, and CFBP 10569 were $59.2,59.2$, and $60.2 \mathrm{~mol} \%$, respectively.

Serological study. The results of the ELISA-I, in which three antisera prepared against $P$. corrugata strains and three antisera prepared against FPTPN strains were used, are shown in Table 6 . The mean absorbance values of negative controls ranged from 0.158 to 0.230 according to the assays, whereas the mean absorbance values of positive controls varied from 1.950 to 2.246 .

Antisera against $P$. corrugata CFBP $2431^{\mathrm{T}}$, CFBP 10147 , and CFBP 10148 reacted with $11(65 \%), 8(47 \%)$, and $11(65 \%)$ of the $17 P$. corrugata strains tested, respectively. Eight strains produced a positive reaction with one serum, five strains produced a positive reaction with two sera, and four strains produced a positive reaction with three sera. The antisera against strains CFBP 10147 and CFBP 10148 reacted with $8(53 \%)$ and $14(93 \%)$ of the 15 FPTPN strains tested, respectively. It was noted that the serum raised against $P$. corrugata type strain CFBP 2431 did not react with any of the FPTPN strains.

Antisera against FPTPN strains CFBP 10529, CFBP 10530, and CFBP 10569 reacted with $7(41 \%), 11(65 \%)$, and $3(18 \%)$ of the $17 P$. corrugata strains tested, respectively, and with 7 $(47 \%), 12(80 \%)$, and $2(13 \%)$ of the 15 FPTPN strains tested, respectively. Five of the FPTPN strains produced a positive reaction with one serum, five produced a positive reaction with two sera, two produced a positive reaction with three sera, and three did not react with any of the three sera tested. The serum against strain CFBP 10530 reacted with most of the $P$. corrugata $(65 \%)$ and FPTPN $(80 \%)$ strains tested, whereas the serum against strain CFBP 10569 reacted only with $19 \%$ of the $P$. corrugata strains and with FPTPN strains of DNA hybridization group 3. The serological results did not show a close correlation with the groups obtained from the phenotypic characterization.

LPS patterns. The LPS patterns were compared on the basis of the number, intensity, coloring, and mobility of the bands in silver-stained polyacrylamide gels. $P$. corrugata strains which have been studied previously produced the same patterns which have been described previously (Table 6) (39). Three additional strains of $P$. corrugata (CFBP 10058, CFBP 10436, and CFBP 10558) produced the new LPS profiles shown in Fig. 
TABLE 4. Levels of DNA relatedness among $P$. corrugata and FPTPN strains

\begin{tabular}{|c|c|c|c|c|c|}
\hline \multirow{3}{*}{ Source of unlabeled DNA } & \multirow{3}{*}{$\begin{array}{l}\text { Phenon or } \\
\text { subphenon }\end{array}$} & \multicolumn{4}{|c|}{$\%$ Relative binding at $70^{\circ} \mathrm{C}$ with labeled DNA from: } \\
\hline & & \multirow{2}{*}{$\begin{array}{l}\text { P. corrugata } \\
\text { CFBP } 2431^{\mathrm{T}}\end{array}$} & \multicolumn{3}{|c|}{ FPTPN strains } \\
\hline & & & CFBP 10529 & CFBP 10530 & CFBP 10569 \\
\hline \multicolumn{6}{|l|}{$P$. corrugata strains } \\
\hline CFBP $2431^{\mathrm{T}}$ & $1 \mathrm{a}$ & 100 & 49 & 45 & $\mathrm{NT}^{a}$ \\
\hline CFBP 10058 & $1 \mathrm{a}$ & 106 & 47 & 45 & NT \\
\hline CFBP 10146 & $1 \mathrm{a}$ & 72 & 49 & 45 & NT \\
\hline CFBP 10886 & $1 \mathrm{a}$ & 99 & 44 & 47 & NT \\
\hline CFBP 10888 & 1a & 91 & 52 & 49 & NT \\
\hline CFBP 10896 & $1 \mathrm{a}$ & 96 & 48 & 52 & NT \\
\hline CFBP 10900 & 1a & 98 & 51 & 49 & NT \\
\hline CFBP 10904 & $1 \mathrm{a}$ & 99 & 46 & 46 & NT \\
\hline CFBP 10905 & $1 \mathrm{a}$ & 80 & 47 & 54 & NT \\
\hline CFBP 10946 & $1 \mathrm{a}$ & $68(2.0)^{b}$ & 48 & 46 & NT \\
\hline CFBP 10148 & $1 b$ & $69(3.0)$ & 51 & 49 & NT \\
\hline CFBP 10558 & $1 b$ & $66(3.0)$ & 47 & 50 & NT \\
\hline CFBP 10883 & $1 \mathrm{~b}$ & $68(3.5)$ & 47 & 45 & NT \\
\hline CFBP 10906 & $1 b$ & 96 & 46 & 44 & NT \\
\hline CFBP 10436 & $2 a$ & 92 & 45 & 40 & NT \\
\hline Avg $\pm \mathrm{SD}$ & & $86.7 \pm 14.4$ & $47.8 \pm 2.3$ & $47.1 \pm 3.5$ & NT \\
\hline \multicolumn{6}{|l|}{ FPTPN strains } \\
\hline \multicolumn{6}{|l|}{ Genomospecies FP1 } \\
\hline CFBP 10552 & $1 \mathrm{a}$ & 52 & 72 & 54 & NT \\
\hline CFBP 10435 & $2 a$ & 47 & 88 & 53 & 23 \\
\hline CFBP 10529 & $2 \mathrm{a}$ & 55 & 100 & 58 & 28 \\
\hline CFBP 10604 & $2 \mathrm{a}$ & 53 & 73 & 40 & NT \\
\hline CFBP 10531 & $2 b$ & 50 & 97 & 48 & NT \\
\hline CFBP 10533 & $2 b$ & 47 & 89 & 54 & NT \\
\hline CFBP 10551 & $2 b$ & 51 & 94 & 58 & NT \\
\hline CFBP 10567 & $2 b$ & 45 & 101 & 50 & 26 \\
\hline CFBP 10591 & $2 b$ & 51 & $67(1.7)$ & 52 & NT \\
\hline $\mathrm{Avg} \pm \mathrm{SD}$ & & $50.1 \pm 3.2$ & $86.8 \pm 13.0$ & $51.9 \pm 5.5$ & $25.7 \pm 2.5$ \\
\hline \multicolumn{6}{|l|}{ Genomospecies FP2 } \\
\hline CFBP 10437 & $2 \mathrm{a}$ & 48 & 60 & 89 & NT \\
\hline CFBP 10605 & $2 \mathrm{a}$ & 45 & 57 & 95 & 24 \\
\hline CFBP 10934 & $2 a$ & 51 & 56 & 94 & NT \\
\hline CFBP 11062 & $2 a$ & 47 & 55 & 93 & 24 \\
\hline CFBP 10530 & $2 b$ & 45 & $60(6.0)$ & 100 & 27 \\
\hline CFBP 10535 & $\mathrm{ip}^{c}$ & 50 & 59 & 101 & NT \\
\hline $\operatorname{Avg} \pm \mathrm{SD}$ & & $47.7 \pm 2.5$ & $57.8 \pm 2.1$ & $95.3 \pm 4.3$ & $25.0 \pm 1.7$ \\
\hline \multicolumn{6}{|l|}{ Genomospecies FP3 } \\
\hline CFBP 10524 & $2 c$ & 20 & 22 & 18 & 93 \\
\hline CFBP 10569 & $2 \mathrm{c}$ & 23 & 26 & 21 & 100 \\
\hline CFBP 10583 & $2 \mathrm{c}$ & 22 & 23 & 22 & 86 \\
\hline $\operatorname{Avg} \pm \mathrm{SD}$ & & $21.7 \pm 1.5$ & $22.7 \pm 2.0$ & $20.3 \pm 2.1$ & $93.0 \pm 7.0$ \\
\hline
\end{tabular}

2. Among the 18 FPTPN strains in phenon 2, 10 different patterns (patterns A to J) were observed (Table 6 and Fig. 2). Ten $(66.7 \%)$ of the 15 strains belonging to DNA hybridization groups 1 and 2 produced LPS pattern A or B, whereas the three DNA hybridization group 3 strains produced three different profiles (patterns $\mathrm{C}, \mathrm{D}$, and $\mathrm{J}$; the last two profiles corresponded to rough type LPS). All of the strains that produced LPS pattern A except strain CFBP 10529 reacted with the antisera against FPTPN strains CFBP 10529 and CFBP 10530 and with the antisera against $P$. corrugata CFBP 10147 and CFBP 10148. Strains that produced LPS pattern B reacted only with the antisera raised against FPTPN strain CFBP 10530 and against $P$. corrugata CFBP 10148. Strains CFBP 10569 and CFBP 10583, with rough type LPS (patterns D and $J$ ), reacted with all of the antisera used except the antiserum prepared against $P$. corrugata type strain CFBP 2431 . 
TABLE 5. Levels of relatedness between DNAs of $P$. corrugata CFBP $2431^{\text {T }}$ and FPTPN strains CFBP 10529 , CFBP 10530 , and CFBP 10569, and DNAs of reference strains of fluorescent and nonfluorescent Pseudomonas, Acidovorax, Burkholderia, Herbaspirillum, and Ralstonia species

\begin{tabular}{|c|c|c|c|c|}
\hline \multirow{3}{*}{ Source of unlabeled DNA } & \multicolumn{4}{|c|}{$\%$ Relative binding at $70^{\circ} \mathrm{C}$ with labeled DNA from: } \\
\hline & \multirow{2}{*}{$\begin{array}{l}\text { P. comugata } \\
\text { CFBP } 2431^{\mathrm{T}}\end{array}$} & \multicolumn{3}{|c|}{ FPTPN strains } \\
\hline & & CFBP 10529 & CFBP 10530 & CFBP 10569 \\
\hline \multicolumn{5}{|c|}{ Fluorescent oxidase-positive Pseudomonas strains } \\
\hline$P$. aeruginosa $\mathrm{CFBP} 2466^{\mathrm{T}}$ & 15 & 13 & 14 & 10 \\
\hline P. agarici CFBP 2063 & 18 & 19 & 21 & 13 \\
\hline P. aspleni CFBP 3279 & 22 & 23 & 26 & 30 \\
\hline P. aureofaciens CFBP $2133^{\mathrm{T}}$ & 28 & 33 & 36 & 26 \\
\hline "P. blatchfordae" CFBP $3280^{\mathrm{T}}$ & 25 & 29 & 32 & 48 \\
\hline P. cichorii CFBP $2101^{\mathrm{T}}$ & 18 & 26 & 23 & 11 \\
\hline P. chlororaphis CFBP $2132^{\mathrm{T}}$ & 28 & 31 & 29 & 24 \\
\hline P. flectens CFBP $3281^{\mathrm{T}}$ & 2 & 0 & 0 & 0 \\
\hline P. fluorescens CFBP $2102^{\mathrm{T}}$ & 24 & 26 & 32 & 42 \\
\hline P. fuscovaginae CFBP $2065^{\mathrm{T}}$ & 21 & 24 & 22 & 17 \\
\hline P. marginalis CFBP $1387^{\mathrm{T}}$ & 22 & 28 & 30 & 45 \\
\hline P. putida CFBP $2066^{\mathrm{T}}$ & 18 & 12 & 30 & 15 \\
\hline P. tolaasii CFBP $2068^{\mathrm{T}}$ & 25 & 27 & 29 & 39 \\
\hline \multicolumn{5}{|c|}{ Fluorescent oxidase-negative Pseudomonas strains } \\
\hline P. caricapapayae CFBP $3204^{\mathrm{T}}$ & 17 & 15 & 19 & 13 \\
\hline P. savastanoi CFBP $1670^{\mathrm{T}}$ & 9 & 9 & 11 & 11 \\
\hline P. syringae pv. syringae CFBP $1392^{\mathrm{T}}$ & 10 & 14 & 14 & 12 \\
\hline P. syringae $\mathrm{pv}$. tomato CFBP $2212^{\mathrm{T}}$ & 10 & 14 & 13 & 14 \\
\hline P. syringae pv. porri CFBP $1908^{\mathrm{T}}$ & 11 & 12 & 8 & 12 \\
\hline \multicolumn{5}{|l|}{ Nonfluorescent Pseudomonas strains } \\
\hline$P$. alcaligenes CFBP $2437^{\mathrm{T}}$ & 11 & 12 & 10 & 2 \\
\hline P. cissicola CFBP $2432^{\mathrm{T}}$ & 3 & 1 & 2 & $\mathrm{NT}^{a}$ \\
\hline P. meliae CFBP 3225 & 0 & 0 & 1 & NT \\
\hline P. stutzeri CFBP $2443^{\mathrm{T}}$ & 0 & 0 & 0 & 1 \\
\hline P. syzygii CFBP 10974 & 0 & 2 & 1 & NT \\
\hline \multicolumn{5}{|l|}{ Acidovorax sp. strains } \\
\hline A. avenae subsp. avenae $\mathrm{CFBP} 2425^{\mathrm{T}}$ & 1 & 2 & 0 & 1 \\
\hline A. avenae subsp. cattleyae CFBP $2423^{\mathrm{T}}$ & 1 & 2 & 4 & 2 \\
\hline A. avenae subsp. citrulli CFBP 10880 & 1 & 1 & 2 & NT \\
\hline A. avenae subsp. konjaci CFBP 10881 & 1 & 4 & 0 & NT \\
\hline \multicolumn{5}{|c|}{ Burkholderia, Herbaspirillum, and Ralstonia spp. strains } \\
\hline B. andropogonis CFBP $2421^{\mathrm{T}}$ & 0 & 5 & 0 & 1 \\
\hline B. caryophilli CFBP $2429^{\mathrm{T}}$ & 3 & 2 & 0 & NT \\
\hline B. cepacia $\mathrm{CFBP} 2227^{\mathrm{T}}$ & 1 & 1 & 1 & 2 \\
\hline B. gladioli CFBP $2427^{\mathrm{T}}$ & 3 & 2 & 0 & NT \\
\hline B. glumae CFBP $2430^{\mathrm{T}}$ & 3 & 2 & 0 & NT \\
\hline B. plantarii CFBP 3199 & 1 & 4 & 0 & NT \\
\hline H. rubrisubalbicans CFBP $1202^{\mathrm{T}}$ & 1 & 1 & 0 & NT \\
\hline R. solanacearum CFBP $2047^{\mathrm{T}}$ & 2 & 1 & 3 & 1 \\
\hline
\end{tabular}

${ }^{a} \mathrm{NT}$, not tested.

FAME profiles. Table 7 shows the fatty acids used in this study. Other fatty acid peaks appeared occasionally in the chromatographic profiles as traces and were not considered for analysis in this study. Numerical analysis of the FAME profiles allowed us to define four main clusters and three isolated strains (Fig. 3). A comparison between the DNA hybridization groups described above and the FAME clusters indicated that cluster I contains only $P$. corrugata strains, which can be differentiated mainly on the basis of four fatty acids $(14: 03 \mathrm{OH}$, 16:0 30H, unknown 13961, and unknown 14503), and that cluster II contains strains belonging to different DNA hybridization groups ( $P$. corrugata and FPTPN strains belonging to DNA hybridization groups 1 and 2). The three DNA hybridization group 3 strains were included in cluster III. Cluster IV contained three DNA hybridization group 1 and 2 FPTPN strains, some of which had a profile with the characteristic fatty acids used to differentiate $P$. corrugata. Table 7 shows the mean percentages of fatty acids in the four different clusters.

Pathogenicity tests. In the first experiment, $28(93 \%)$ of the $30 P$. corrugata strains tested and $13(93 \%)$ of the 14 FPTPN strains belonging to DNA hybridization groups 1 and 2 tested produced typical symptoms (i.e., necrosis and pith hollowing) on at least one of the five inoculated tomato plants. The development of external symptoms (browning of stem surface and adventious roots) and the length of pith necrosis were variable according to strain. In contrast, none of the three FPTPN strains belonging to DNA hybridization group 3 (strains CFBP 10524, CFBP 10569, and CFBP 10583) produced typical symptoms of pith necrosis. No symptoms were observed in control plants. 
TABLE 6. ELISA-I reactivities and LPS patterns of $P$. corrugata and FPTPN strains

\begin{tabular}{|c|c|c|c|c|c|c|c|c|}
\hline \multirow{3}{*}{ Strain } & \multirow{3}{*}{$\begin{array}{l}\text { Phenon or } \\
\text { subphenon }\end{array}$} & \multicolumn{6}{|c|}{ Reactivity in ELISA-I with antiserum against: } & \multirow{3}{*}{$\begin{array}{c}\text { LPS } \\
\text { pattern }^{b}\end{array}$} \\
\hline & & \multicolumn{3}{|c|}{ P. corrugata strains } & \multicolumn{3}{|c|}{ FPTPN strains } & \\
\hline & & $\begin{array}{l}\text { CFBP } \\
2431^{T}\end{array}$ & $\begin{array}{l}\text { CFBP } \\
10147\end{array}$ & $\begin{array}{l}\text { CFBP } \\
10148\end{array}$ & $\begin{array}{l}\text { CFBP } \\
10529\end{array}$ & $\begin{array}{l}\text { CFBP } \\
10530\end{array}$ & $\begin{array}{l}\text { CFBP } \\
10569\end{array}$ & \\
\hline \multicolumn{9}{|l|}{$P$. corrugata strains } \\
\hline CFBP $2431^{\mathrm{T}}$ & 1a & $+^{a}$ & - & - & - & + & - & 1 \\
\hline CFBP 10058 & $1 \mathrm{a}$ & - & + & + & + & + & - & NP \\
\hline CFBP 10060 & 1a & + & - & - & - & - & - & 1 \\
\hline CFBP 10145 & 1a & + & + & + & - & + & - & 2 \\
\hline CFBP 10147 & 1a & + & + & - & - & + & - & ND \\
\hline CFBP 10148 & $1 b$ & - & + & + & + & + & - & 3 \\
\hline CFBP 10436 & $2 \mathrm{a}$ & - & - & + & - & - & - & NP \\
\hline CFBP 10553 & 1a & + & - & + & - & - & - & ND \\
\hline CFBP 10558 & $1 b$ & - & + & + & + & + & + & $\mathrm{NP}$ \\
\hline CFBP 10883 & $1 b$ & + & + & + & + & + & + & 6 \\
\hline CFBP 10886 & $1 \mathrm{a}$ & - & - & + & - & + & - & 4 \\
\hline CFBP 10888 & $1 \mathrm{a}$ & + & - & - & - & - & - & 1 \\
\hline CFBP 10896 & $1 \mathrm{a}$ & - & - & + & + & + & - & 11 \\
\hline CFBP 10900 & $1 \mathrm{a}$ & + & + & + & + & + & - & 14 \\
\hline CFBP 10904 & $1 \mathrm{a}$ & + & - & - & - & - & - & 5 \\
\hline CFBP 10905 & 1a & + & - & - & - & - & - & 1 \\
\hline CFBP 10906 & $1 \mathrm{~b}$ & + & + & + & + & + & + & 3 \\
\hline \multicolumn{9}{|c|}{ FPTPN strains } \\
\hline \multicolumn{9}{|c|}{ Genomospecies FP1 } \\
\hline CFBP 10435 & $2 a$ & - & - & + & - & - & - & G \\
\hline CFBP 10529 & $2 \mathrm{a}$ & - & - & - & + & + & - & A \\
\hline CFBP 10531 & $2 \mathrm{~b}$ & - & - & + & - & + & - & B \\
\hline CFBP 10533 & $2 \mathrm{~b}$ & NT & NT & NT & NT & NT & NT & B \\
\hline CFBP 10551 & $2 b$ & - & - & + & - & + & - & $\mathrm{B}$ \\
\hline CFBP 10552 & $1 \mathrm{~b}$ & - & + & + & + & + & - & A \\
\hline CFBP 10567 & $2 b$ & - & - & + & - & + & $\rightarrow$ & B \\
\hline CFBP 10591 & $2 \mathrm{~b}$ & - & + & + & - & - & - & $\mathrm{E}$ \\
\hline CFBP 10604 & $2 \mathrm{a}$ & - & + & + & - & + & - & $\mathrm{F}$ \\
\hline \multicolumn{9}{|c|}{ Genomospecies FP2 } \\
\hline CFBP 10437 & $2 a$ & - & + & + & + & + & - & A \\
\hline CFBP 10530 & $2 b$ & - & - & + & - & + & - & B \\
\hline CFBP 10535 & 2 & NT & NT & NT & NT & NT & NT & $\mathrm{H}$ \\
\hline CFBP 10605 & $2 a$ & - & + & + & + & + & - & A \\
\hline CFBP 10934 & $2 \mathrm{a}$ & NT & NT & NT & NT & NT & NT & I \\
\hline CFBP 11062 & $2 \mathrm{a}$ & - & + & + & + & + & - & A \\
\hline \multicolumn{9}{|c|}{ Genomospecies FP3 } \\
\hline CFBP 10524 & $2 c$ & - & - & + & - & - & - & $\mathrm{C}$ \\
\hline CFBP 10569 & $2 \mathrm{c}$ & - & + & + & + & + & + & $\mathrm{D}$ \\
\hline CFBP 10583 & $2 c$ & - & + & + & + & + & + & $\mathrm{J}$ \\
\hline
\end{tabular}

${ }^{a}+$, positive; -, negative; NT, not tested. A reaction was considered positive when the absorbance was twice the absorbance of the negative control in each plate ${ }^{b}$ ND, not determined; NP, new LPS profile for $P$. corrugata (see Fig. 2). The numbers are designations for LPS profiles previously described by Siverio et al. (39), and the letters are designations for LPS profiles determined for FPTPN strains (Fig. 2).

The results of the second experiment, in which we inoculated two strains of $P$. corrugata and four FPTPN strains into pepper, tobacco, bean, cauliflower, melon, cucumber, and zucchini plants, are shown in Table 8 . No symptoms were observed in any of the control plants except some melon and cucumber plants which, for unknown reasons, showed slight symptoms of pith necrosis. Nevertheless; no pseudomonads were isolated from the lesions. $P$. corrugata and FPTPN strains were able to cause pith necrosis in pepper, tobacco, bean, cauliflower, melon, and cucumber plants. No symptoms were observed in zucchini plants. A great deal of variability was observed in the length of the necrosis in the plants inoculated with each strain of $P$. corrugata, as well as with FPTPN strains. The pith necrosis obtained differed slightly in different hosts in color, intensity, and extension to other tissues. Colonies with the charac- teristics of $P$. corrugata or of fluorescent strains were reisolated from the edges of the lesions.

\section{DISCUSSION}

In this study, we compared a collection of 33 FPTPN strains with $89 P$. corrugata strains and with 74 reference strains of fluorescent and nonfluorescent Pseudomonas, Acidovorax, Burkholderia, Herbaspirillum, and Ralstonia species.

A numerical analysis of the results obtained in 167 biochemical and physiological tests was performed. Eighty-eight of the $89 P$. corrugata strains, including type strain CFBP 2431, formed a single cluster (phenon 1). These strains are nonfluorescent on King B medium, do not produce levan, are oxidase positive and nonpectolytic, reduce nitrates, and accumulate 


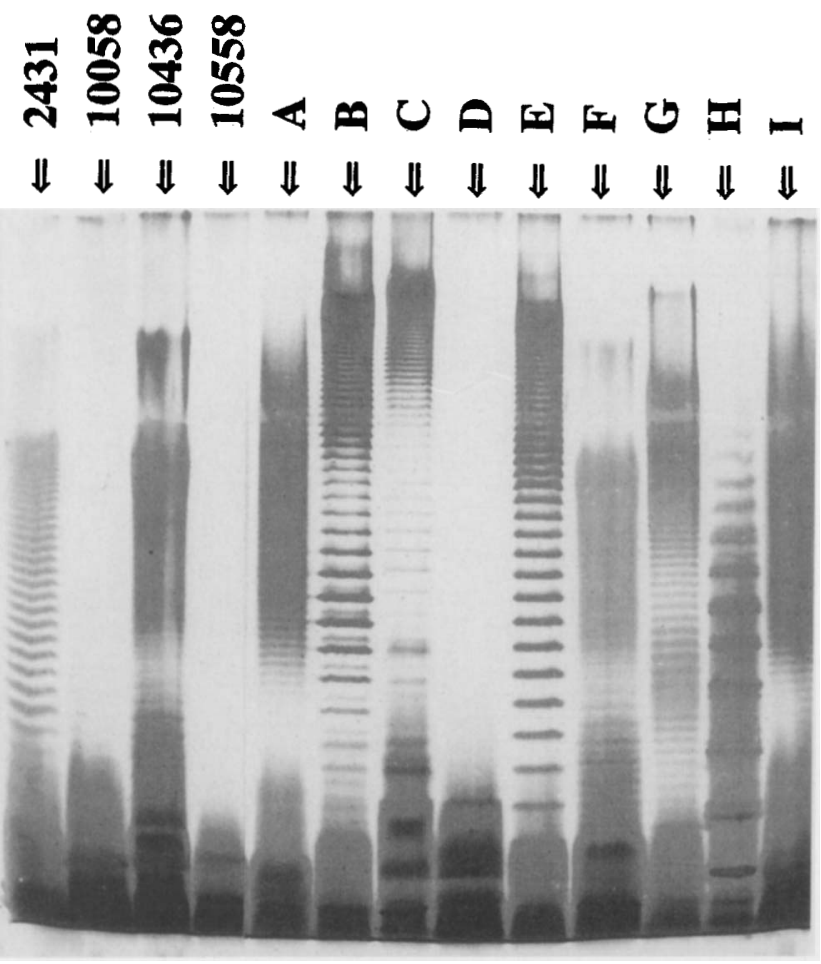

FIG. 2. Polyacrylamide gel electrophoresis of whole-cell lysates treated with proteinase $\mathrm{K}$, showing the different LPS patterns. The $P$. corrugata strains used were CFBP $2431^{\mathrm{T}}$, CFBP 10058 , CFBP 10436, and CFBP 10558, which had a profile without an O-chain (rough type LPS). The following FPTPN strains were used; lane A, CFBP 10529; lane B, CFBP 10533; lane C, CFBP 10524; lane D, CFBP 10569 (rough type LPS); lane E, CFBP 10591; lane F, CFBP 10604; lane G, CFBP 10435; lane H, CFBP 10535; and lane I, CFBP 10934. The letters correspond to the LPS patterns in Table 6.
PHB, as previously described $(25,35,39)$. The results of previous studies performed with a limited number of strains are contradictory with regard to arginine dihydrolase activity in $P$. corrugata and the ability of this organism to induce a hypersensitive reaction on tobacco leaves $(19,25,35,39)$. Our results obtained with a large number of strains indicated that $77 \%$ of the $P$. corrugata strains tested are positive for arginine dihydrolase activity, provided that a long incubation time (at least 15 days) is used, and that only $19 \%$ of the $P$. corrugata strains tested produce a hypersensitivity reaction on tobacco leaves. Thus, the results of these tests are variable for this species. These characteristics correspond approximately to the characteristics of group $\mathrm{Va}$ in the LOPAT determinative scheme (24), which also includes saprophytic and pathogenic fluorescent $P$ seudomonas species, such as $P$. fluorescens, $P$. putida, and $P$. aeruginosa.

Considering the phenotypic distances between the different clusters, $P$. corrugata appeared to be very closely related to FPTPN strains and more closely related to fluorescent Pseudomonas species than to nonfluorescent Pseudomonas, Acidovorax, Herbaspirillum, and Burkholderia species. Nevertheless, $P$. corrugata can be clearly distinguished by many phenotypic characteristics from the major plant-pathogenic or saprophytic, fluorescent, oxidase-positive Pseudomonas species, such as $P$. cichorii, $P$. fuscovaginae, $P$. tolaasii, $P$. marginalis, $P$. fluorescens, and $P$. putida. Our phenotypic results, obtained with a large number of strains and with numerous tests, are very informative and should be useful for precisely defining the species $P$. corrugata. Our phenotypic observations are strengthened by our DNA-DNA reassociation results; the levels of hybridization obtained with labeled DNA from $P$. corrugata type strain CFBP 2431 were as high as $55 \%$ with FPTPN strains and varied from 15 to $28 \%$ with the type strains of fluorescent Pseudomonas species, but were generally less than $5 \%$ with the type strains of nonfluorescent Pseudomonas, Acidovorax, Burkholderia, Herbaspirillum, and Ralstonia species.

TABLE 7. Fatty acid compositions of the clusters obtained by numerical analysis ${ }^{a}$

\begin{tabular}{|c|c|c|c|c|c|c|c|c|}
\hline \multirow{3}{*}{$\mathrm{FAME}^{b}$} & \multicolumn{8}{|c|}{ Fatty acid compositions } \\
\hline & \multicolumn{2}{|c|}{ Cluster I $(n=7)^{c}$} & \multicolumn{2}{|c|}{ Cluster II $(n=17)$} & \multicolumn{2}{|c|}{ Cluster III $(n=3)$} & \multicolumn{2}{|c|}{ Cluster IV $(n=3)$} \\
\hline & $\begin{array}{l}\text { Mean \% } \\
\text { (SD) }\end{array}$ & $\begin{array}{l}\text { No. of strains } \\
\text { with fatty acid }\end{array}$ & $\begin{array}{l}\text { Mean \% } \\
\text { (SD) }\end{array}$ & $\begin{array}{l}\text { No. of strains } \\
\text { with fatty acid }\end{array}$ & $\begin{array}{l}\text { Mean \% } \\
(\mathrm{SD})\end{array}$ & $\begin{array}{l}\text { No. of strains } \\
\text { with fatty acid }\end{array}$ & $\begin{array}{c}\text { Mean \% } \\
\text { (SD) }\end{array}$ & $\begin{array}{l}\text { No. of strains } \\
\text { with fatty acid }\end{array}$ \\
\hline $10: 0$ & $0.42(0.11)$ & 7 & $0.18(0.06)$ & 17 & $0.06(0.02)$ & 3 & $0.32(0.07)$ & 3 \\
\hline $10: 03 \mathrm{OH}$ & $4.28(0.28)$ & 7 & $3.68(0.31)$ & 17 & $3.14(0.35)$ & 3 & $3.76(0.19)$ & 3 \\
\hline $12: 0$ & $3.59(0.51)$ & 7 & $5.23(0.70)$ & 17 & $2.90(0.04)$ & 3 & $3.93(0.49)$ & 3 \\
\hline Unknown 12486 & $0.21(0.05)$ & 7 & $0.09(0.07)$ & 13 & $0.07(0.01)$ & 3 & $0.42(0.13)$ & 3 \\
\hline $12: 02 \mathrm{OH}$ & $3.92(0.49)$ & 7 & $3.10(0.48)$ & 17 & $4.49(0.08)$ & 3 & $3.94(0.33)$ & 3 \\
\hline $12: 13 \mathrm{OH}$ & $0.79(0.24)$ & 7 & $0.09(0.08)$ & 12 & $0.01(0.01)$ & 1 & $0.74(0.19)$ & 3 \\
\hline $12: 03 \mathrm{OH}$ & $4.52(0.29)$ & 7 & $4.15(0.26)$ & 17 & $4.30(0.03)$ & 3 & $4.39(0.33)$ & 3 \\
\hline Unknown 13961 & $0.84(0.21)$ & 7 & $0.00(0.00)$ & 0 & $0.00(0.00)$ & 0 & $0.08(0.12)$ & 1 \\
\hline $14: 0$ & $0.06(0.08)$ & 3 & $0.35(0.07)$ & 17 & $0.47(0.06)$ & 3 & $0.30(0.05)$ & 3 \\
\hline Unknown 14503 & $0.63(0.21)$ & 7 & $0.00(0.00)$ & 0 & $0.00(0.00)$ & 0 & $0.15(0.14)$ & 2 \\
\hline $15: 0$ & $0.02(0.03)$ & 2 & $0.02(0.04)$ & 5 & $0.07(0.01)$ & 3 & $0.17(0.01)$ & 3 \\
\hline $14: 03 \mathrm{OH}$ & $0.98(0.23)$ & 7 & $0.00(0.02)$ & 1 & $0.00(0.00)$ & 0 & $0.72(0.51)$ & 3 \\
\hline 16:1 cis 9 & $30.23(1.44)$ & 7 & $35.63(1.61)$ & 17 & $31.02(0.08)$ & 3 & $33.14(2.22)$ & 3 \\
\hline $16: 0$ & $26.42(0.72)$ & 7 & $27.21(1.99)$ & 17 & $29.19(1.57)$ & 3 & $24.88(0.75)$ & 3 \\
\hline 17:0 cyclo & $2.91(0.65)$ & 7 & $0.90(0.73)$ & 15 & $2.16(0.73)$ & 3 & $2.39(0.48)$ & 3 \\
\hline $17: 0$ & $0.01(0.03)$ & 1 & $0.06(0.07)$ & 8 & $0.14(0.04)$ & 3 & $0.29(0.04)$ & 3 \\
\hline $16: 03 \mathrm{OH}$ & $0.60(0.16)$ & 7 & $0.00(0.00)$ & 0 & $0.00(0.00)$ & 0 & $0.22(0.31)$ & 1 \\
\hline $18: 1$ cis 11 & $18.60(0.84)$ & 7 & $18.71(2.42)$ & 17 & $20.89(2.33)$ & 3 & $19.31(0.40)$ & 3 \\
\hline $18: 0$ & $0.67(0.08)$ & 7 & $0.55(0.16)$ & 17 & $0.89(0.07)$ & 3 & $0.73(0.22)$ & 3 \\
\hline $19: 0$ cyclo $11-12$ & $0.30(0.13)$ & 7 & $0.04(0.10)$ & 4 & $0.20(0.05)$ & 3 & $0.12(0.08)$ & 2 \\
\hline
\end{tabular}

${ }^{a}$ Clusters as shown in the fatty acid dendrogram in Fig. 3.

${ }^{b}$ The numbers in the unknown FAME designations are the equivalent chain lengths.

$c$ The numbers in parentheses are the numbers of strains in the clusters. 


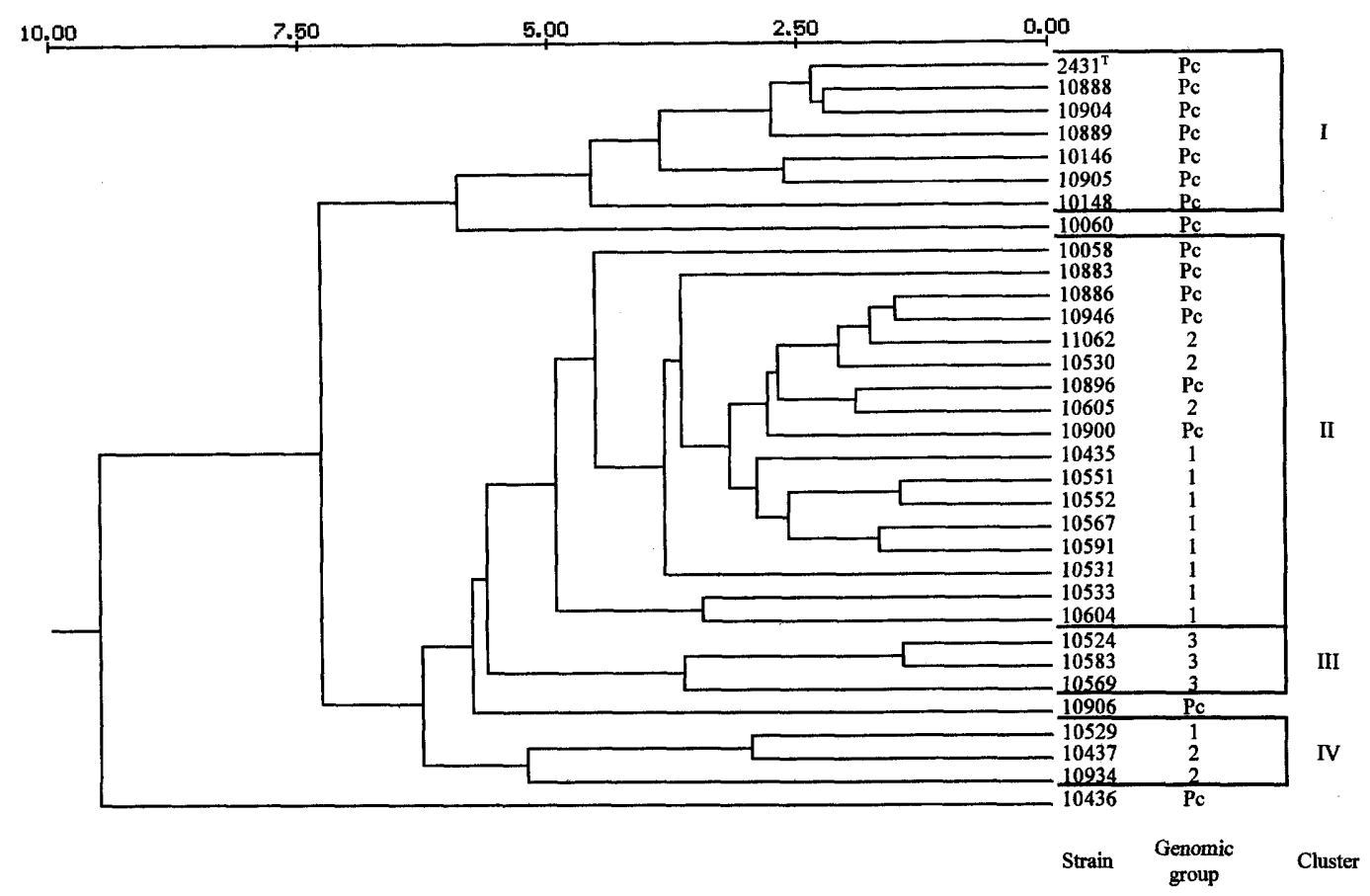

FIG. 3. Dendrogram based on the results of the fatty acid cluster analysis, showing the relationships among 33 Pseudomonas strains isolated from tomato and pepper with pith necrosis. Abbreviations: Pc, P. comugata; 1, Pseudomonas genomospecies FP1; 2, Pseudomonas genomospecies FP2; 3 , Pseudomonas genomospecies FP3.

By using DNA-rRNA hybridization, it has been demonstrated that $P$. corrugata belongs to superfamily 2 and to the $P$. fluorescens rRNA branch now considered the authentic pseudomonads $(11,12)$. However, as a nonfluorescent species, $P$. corrugata, like Pseudomonas amygdali, could be considered anomalous in this rRNA branch (48). Moreover, chemotaxonomic studies based on analyses of quinones and fatty acids have placed $P$. corrugata in the same fluorescent Pseudomonas group (42).

In the present study, $P$. comigata phenon 1 was divided into two subphena, subphena $1 \mathrm{a}$ and $1 \mathrm{~b}$, which were differentiated by the following three biochemical tests: assimilation of mesotartrate, isobutyrate, and histamine. We did not observe any correlation between the geographic origin of the $P$. corrugata strains and their distribution in subphena $1 \mathrm{a}$ and $1 \mathrm{~b}$. No correlation was found between the subdivision of phenon 1 into subphena $1 \mathrm{a}$ and $1 \mathrm{~b}$ on the basis of phenotypic characteristics and the results of DNA-DNA hybridizations. The accepted molecular definition of a bacterial genomic species (genomo- species) is applied to strains whose levels of DNA-DNA hybridization are around $70 \%$, with $\Delta T_{m}$ values of $5^{\circ} \mathrm{C}$ or less (46). Our DNA-DNA hybridization results obtained with labeled DNA from $P$. corrugata type strain CFBP 2431 indicated clearly that $P$. corrugata strains belong to a single genomic group and confirmed that the data for $P$. corrugata are consistent with the definition of a bacterial species (46). The $\mathrm{G}+\mathrm{C}$ content of type strain CFBP $2431^{\mathrm{T}}(59.6 \mathrm{~mol} \%)$ was similar to the values previously reported for $P$. corrugata (11). However, the range of levels of DNA reassociation (66 to 106\%) provides evidence of genomic variability in the $P$. corrugata strains tested here. These results could be related to the long evolution of a weakly pathogenic bacterium. Nevertheless, as the genomic diversity is not strictly correlated with phenotypic clustering, we do not propose that $P$. corrugata should be split into subspecies. However, in our opinion, it would be very interesting to further study the genomic diversity of $P$. corrugata at the infraspecific level by molecular techniques, such as

TABLE 8. Pathogenicity of $P$. corrugata and FPTPN strains for different host plants

\begin{tabular}{|c|c|c|c|c|c|c|c|}
\hline \multirow{2}{*}{ Strain } & \multicolumn{7}{|c|}{ Pathogenicities for the following host plants: } \\
\hline & Pepper & Tobacco & Bean & Cauliflower & Melon & Cucumber & Zucchini \\
\hline \multicolumn{8}{|l|}{$P$. corrugata strains } \\
\hline CFBP $2431^{\mathrm{T}}$ & $+^{a}$ & ++ & ++ & ++ & + & + & - \\
\hline CFBP 10148 & ++ & + & + & + & - & + & - \\
\hline \multicolumn{8}{|l|}{ FPTPN strains } \\
\hline CFBP 10529 (genomospecies FP1) & + & ++ & ++ & ++ & - & - & - \\
\hline CFBP 10530 (genomospecies FP2) & + & + & ++ & + & - & + & - \\
\hline CFBP 10934 (genomospecies FP2) & + & ++ & + & ++ & - & + & - \\
\hline CFBP 10583 (genomospecies FP3) & - & - & + & ++ & + & + & - \\
\hline
\end{tabular}

${ }^{a}-$, no internal or external lesions observed; + , pith necrosis 10 to $20 \mathrm{~mm}$ long, ++ , pith necrosis more than $20 \mathrm{~mm}$ long. 
restriction fragment length polymorphism or randomly amplified polymorphic DNA analysis.

Seventeen of the 33 FPTPN strains belonged to phenon 2, and one (strain CFBP 10552) belonged to $P$. corrugata phenon 1. The strains in phenon 2 can be distinguished from $P$. corrugata strains by the following four biochemical characteristics: production of fluorescent pigment on King B medium, accumulation of PHB, levan formation, and assimilation of sorbitol. Moreover, phenon 2 contained one $P$. corrugata strain (CFBP 10436), and, conversely, $P$. corrugata phenon 1 contained one FPTPN strain (CFBP 10552). Consequently, these two phena are closely related phenotypically. This could be explained by phytopathological specialization, as the organisms produced gave similar symptoms on the same host plant, tomato. However, DNA-DNA hybridizations revealed that these 18 FPTPN strains are clearly separate from $P$. corrugata and belong to three different DNA hybridization groups that could be proposed as new species (46). The $G+C$ contents of these DNA hybridization groups, which varied from 59.2 to $60.2 \mathrm{~mol} \%$, fall within the range of $\mathrm{G}+\mathrm{C}$ contents of the genus Pseudomonas $(55.2$ to $67.2 \mathrm{~mol} \%)(11,31)$. As suggested by Johnson (20) in a discussion of the significance of levels of DNA-DNA hybridization between genomic species, we compared the levels of DNA-DNA hybridization between $P$. corrugata and FPTPN strains; these values indicated that DNA hybridization groups 1 and 2 are closely related (levels of hybridization, 51.9 to $57.8 \%$ ) to each other and are related to $P$. corrugata (levels of hybridization, 47.1 to $47.8 \%$ ), whereas DNA hybridization group 3 is less closely related to DNA hybridization groups 1 and 2 (levels of hybridization, 20.3 to $25.7 \%$ ) and to $P$. corrugata (levels of hybridization, 20 to $23 \%$ ). The strains of DNA hybridization groups 1 and 2 are distributed at random in subphena $2 \mathrm{a}$ and $2 \mathrm{~b}$ and cannot be clearly distinguished by phenotypic tests. DNA hybridization group 3, containing only three strains, can be distinguished from DNA hybridization groups 1 and 2 by only two biochemical tests (assimilation of citraconate and laevulinate) and by the absence of virulence on tomato plants under our experimental conditions. Because of the lack or insufficiency of discriminating phenotypic tests and the low number of strains in DNA hybridization group 3, DNA hybridization groups 1,2 , and 3 are designated Pseudomonas genomospecies FP1, FP2, and FP3 (FP for fluorescent Pseudomonas), respectively, rather than given formal names and proposed as new species.

The involvement of fluorescent Pseudomonas spp. strains in tomato pith necrosis has been described previously in different countries $(3,6,13)$. Strains CFBP 10435 and CFBP 10437, isolated in Canada and previously described as a novel agent of tomato stem necrosis (13), belong to Pseudomonas genomospecies FP1 and FP2, respectively.

Of the remaining 15 FPTPN strains which did not cluster in phenon 2, 2 strains clustered in phenon 12, which is closely related to $P$. cichorii (phenon 11); these two strains correspond to group III of Leliott et al. (24) and could be considered $P$. cichorii strains. Five strains which clustered in $P$. marginalis (phenon 5), two of which (CFBP 10539 and CFBP 10549) were pectolytic, were identified as strains of $P$. marginalis (group IVa of Leliott et al. [24]). One strain (CFBP 10582) was included with $P$. tolaasii in phenon 6 but does not have typical phenotypic characteristics of $P$. tolaasii (36). Two strains (CFBP 10601 and CFBP 10602) clustered in phenon 8 and were identified as $P$. aeruginosa strains. It was impossible to identify the last five strains, which were isolated phenotypes. To our knowledge, among the well-characterized fluorescent phytopathogenic Pseudomonas species, only $P$. cichorii has been described as a causal agent of tomato pith necrosis in New Zealand (47).
However, the involvement of pectolytic $P$. marginalis strains in this disease cannot be definitively ruled out. No clear conclusion concerning the strains related to saprophytic fluorescent Pseudomonas species, such as $P$. fluorescens and $P$. aeruginosa, can be reached in the absence of results concerning the pathogenicity of these strains on tomato plants.

The LPS characteristics of $P$. corrugata and FPTPN strains were investigated by using a procedure that facilitates the differentiation of these strains. However, the same LPS profiles may occasionally have different compositions (39), and it is necessary to use biochemical or serological techniques to verify them. New LPS profiles, different from those previously described (39), were observed in the $P$. corrugata strains studied. In FPTPN strains, original LPS profiles that were different from those of $P$. corrugata strains (39; this study) were observed. Our results show that the genomospecies delineated by DNA-DNA hybridization include strains which have different LPS profiles, indicating that there is LPS heterogeneity within each genomospecies. However, some LPS profiles coincide with different genomospecies, particularly genomospecies FP1 and FP2. Therefore, although different at the genomic level, strains of these two genomospecies can have LPS structures in common. Strains of genomospecies FP3 have LPS profiles different from those of genomospecies FP1 and FP2. This observation, together with the results of numerical taxonomy and DNA-DNA hybridization analyses, indicate that genomospecies FP3 has a low-level relationship with genomospecies FP1 and FP2. The serological variability of $P$. corrugata strains has been investigated previously (39) and is attributed mainly to variations in the composition of LPS. $P$. corrugata and FPTPN strains were serotyped by performing an ELISA-I with antisera raised against strains belonging to these two groups. A high level of serological variability was observed in the strains. The reactivities of $P$. corrugata strains with the three anti- $P$. corrugata sera tested and the reactivities of FPTPN strains with the three sera raised against FPTPN strains were very variable; a similar phenomenon has been reported previously for $P$. corrugata isolates from Spain and Italy $(6,39)$. Moreover, crossreactions (i.e., reactivity of anti- $P$. corrugata sera with FPTPN strains and reactivity of sera against FPTPN strains with $P$. corrugata) were observed. These cross-reactions indicate that $P$. corrugata and FPTPN strains share common epitopes in spite of their heterogeneity. For FPTPN strains, serological reactions seem to be directly related to LPS profiles, since strains with the same LPS profile reacted with the same antisera, as previously observed for $P$. corrugata (39).

Numerical analysis of FAME profiles revealed that most (about $80 \%$ ) of the $P$. corrugata strains studied were distributed in two clusters, clusters I and II. Cluster I plus strain CFBP 10060, which is closely attached to this cluster, had a characteristic $P$. corrugata profile with four fatty acids (14:0 $3 \mathrm{OH}, 16: 03 \mathrm{OH}$, unknown 13961, and unknown 14503), as previously described (42), whereas the strains in cluster II had a different profile. This difference might be associated with changes in the morphological aspect of colonies, as previously reported for this species (40) and for Burkholderia cepacia and Burkholderia gladioli (43). Although this phenomenon was not investigated here, this hypothesis is supported by the fact that cluster II strains had a profile with peak areas within the range described for $P$. corrugata strains along with differences in colony morphology (40). Strains belonging to genomospecies FP1 and FP2 overlap in the peak areas of their profiles in cluster II (along with six $P$. corrugata strains) and cluster IV (sometimes with characteristic peaks of $P$. corrugata). Consequently, the FAME analysis did not permit differentiation of genomospecies FP1 and FP2, which had profiles similar to the 
profiles of other species, such as $P$. cichorii, Pseudomonas viridiflava, and Pseudomonas syringae (42) (first choices with a high level of similarity when the MIDI identification system was used). The three strains of genomospecies FP3 had a low degree of variation in peak area percentages, but they had a profile similar to the profiles of species such as $P$. marginalis, $P$. fluorescens, and $P$. putida (42) (first choices with a high level of similarity when the MIDI identification system was used).

Inoculation of tomato plants in the greenhouse indicated that a large majority of the $P$. corrugata strains $(93 \%)$ produced typical symptoms, mainly pith necrosis and hollowing, as previously reported $(25,35,39)$. Most $(93 \%)$ of the FPTPN strains belonging to genomospecies FP1 and FP2 also produced these typical symptoms. The intensity and the extent of the symptoms varied a great deal with the strain for both $P$. corrugata and FPTPN strains. Strains of genomospecies FP3 did not produce any symptoms, suggesting either that they are nonpathogenic or that the conditions which we used were not favorable for these strains. Both $P$. corrugata and FPTPN strains induced pith necrosis symptoms in plants other than tomato (i.e., pepper, tobacco, bean, cauliflower, melon, and cucumber) but not in zucchini. The symptoms in these different hosts were similar to those reported by Siverio (38), but in that previous study, symptoms in zucchini were also observed. In the present study, the number of strains tested was limited, and therefore, no definitive conclusion can be drawn concerning the host ranges of $P$. corrugata and FPTPN strains. Although natural infections have been observed in a limited number of host plants (tomato, pepper, and chrysanthemum) $(14,25,35)$, our results suggest that these bacteria have a broad pathogenic potential, which is a characteristic of opportunistic organisms. It can be supposed that under favorable conditions, $P$. corrugata and FPTPN strains can cause symptoms not only on tomato, but also on many cultivated plants of different species.

Thus, we confirmed that tomato pith necrosis can be due to different Pseudomonas species (mainly $P$. corrugata, but also fluorescent oxidase-positive Pseudomonas species), as previously reported $(3,6,13)$. On the basis of DNA-DNA hybridization, physiological, and biochemical characteristics, serological data, LPS patterns, FAME profiles, and pathogenicity test data, below we provide an emended description of $P$. corrugata and descriptions of three new fluorescent Pseudomonas genomospecies, designated genomospecies FP1, FP2, and FP3.

Emended description of Pseudomonas corrugata Roberts and Scarlett 1981. $P$. corrugata is a gram-negative, non-spore-forming rod. Colonies on YBGA are wrinkled or smooth and frequently produce yellow to brown pigments. Mobile cells have multiple polar flagella, as previously reported (35). This organism is strictly aerobic, nonfluorescent on King B medium, and oxidase positive, does not produce levan, is not pectolytic, reduces nitrates into nitrites, and accumulates PHB as previously described $(25,35,39)$. Most (about $80 \%$ ) of the strains are arginine dihydrolase positive after 15 days of incubation, and a few (about $20 \%$ ) of the strains produce hypersensitivity on tobacco leaves. Hydrolysis of Tween 80 and hydrolysis of gelatin are variable.

$P$. corrugata strains utilize acetate, $N$-acetylglucosamine, aconitate, D- and L-alanine, DL-4-aminobutyrate, DL-5-aminovalerate, D-arabitol, L-arabinose, L-arginine, L-aspartate, betaine, caprate, $n$-caproate, caprylate, citrate, diaminobutane, D-fructose, fumarate, D-galactose, glucosamine, D-glucose, gluconate, L-glutamate, glutarate, glycerol, heptanoate, L-histidine, DL-3-hydroxybutyrate, $p$-hydroxybenzoate, inositol, L-isoleucine, 2-ketoglutarate, DL-lactate, L-leucine, L-malate, malonate, mannitol, D-mannose, pelargonate, L-phenylalanine, L-proline, propionate, ribose, sarcosine, L-serine, spermine, saccharose, succinate, threalose, trigonelline, L-tyrosine, $n$-valerate, L-valine, and D-xylose.

In contrast, they do not hydrolyze starch, DNA, and esculin and do not utilize acetamide, adipate, adonitol, 2-, 3-, and 4-aminobenzoate, DL-2-aminobutyrate, amygdalin, D-arabinose, L-arabitol, arbutin, azelate, benzoate, benzylamine, butylamine, D-cellobiose, L-citrulline, creatine, L-cysteine, dulcitol, ethylamine, erythritol, D- and L-fucose, D-gentobiose, glycine, glycogen, glycolate, $o$ - and $m$-hydroxybenzoate, inulin, itaconate, 5-ketogluconate, DL-kynurenine, lactose, laevulinate, maleate, maltose, $\mathrm{D}$ - and L-mandelate, D-melezitose, Dmelibiose, mesaconate, L-methionine, methyl-D-glucoside, methyl-D-mannoside, methylxyloside, DL-norvaline, oxalate, phenylacetate, phthalate, isophthalate, ter-phthalate, pimelate, D-raffinose, rhamnose, salicin, sebacate, sorbitol, suberate, Ltartrate, D-tagatose, L-threonine, tryptamine, D- and L-tryptophan, D-turanose, urea, xylitol, and L-xylose.

Utilization of the following substrates is variable: DL-3-aminobutyrate, amylamine, butyrate, isobutyrate, citraconate, ethanolamine, DL-glycerate, histamine, 2-ketogluconate, L-lysine, D-lyxose, D-malate, L-norleucine, L-ornithine, isovalerate, Dtartrate, meso-tartrate, and pyruvate.

The levels of DNA relatedness of $P$. corrugata strains with type strain CFBP 2431 range from 66 to $99 \%$ (as determined by the $\mathrm{S} 1$ nuclease-trichloroacetic acid method). The $\mathrm{G}+\mathrm{C}$ content of the DNA is 58.4 to $60.8 \mathrm{~mol} \%$ (11; this study).

Description of Pseudomonas genomospecies FP1, FP2, and FP3. Pseudomonas genomospecies FP1, FP2, and FP3 are gram-negative rods which are mobile by means of multiple polar flagella. The strains are oxidase positive and strictly aerobic, produce fluorescent pigment on King B medium, do not accumulate $\mathrm{PHB}$, are arginine dihydrolase positive, and reduce nitrates into nitrites. They are not pectolytic and do not induce hypersensitivity on tobacco leaves.

Strains of Pseudomonas genomospecies FP1, FP2, and FP3 utilize ethanolamine, DL-glycerate, isobutyrate, isovalerate, 2ketogluconate, D-lyxose, and D-malate. Utilization of saccharose, succinate, trigonelline, and $\mathrm{D}$-xylose is variable.

Strains of Pseudomonas genomospecies FP1 and FP2, which cannot be distinguished phenotypically, produce levan and utilize sorbitol but not citraconate and laevulinate. Hydrolysis of gelatin and Tween 80 and assimilation of itaconate, $N$-acetylglucosamine, amylamin, and glycine are variable.

Strains of Pseudomonas genomospecies FP3 hydrolyze gelatin but not Tween 80 and utilize citraconate, laevulinate, and $\mathrm{N}$-acetylglucosamine but not itaconate, amylamine, and glycine. Production of levan and utilization of sorbitol are variable.

Assimilation of the other organic substrates tested is the same for strains of Pseudomonas genomospecies FP1, FP2, and FP3 as for $P$. corrugata strains (see above).

The FAME profiles of strains of Pseudomonas genomospecies FP1 and FP3 are similar to those of $P$. cichorii, $P$. viridiflava, and $P$. syringae strains. The FAME profiles of strains of Pseudomonas genomospecies FP3 are similar to those of $P$. fluorescens and $P$. putida strains. The LPS patterns on silverstained polyacrylamide electrophoresis gels of strains of Pseudomonas genomospecies FP1, FP2, and FP3 are different from those of $P$. corrugata strains. Strains of Pseudomonas genomospecies FP1 and FP2 have the same LPS patterns, whereas strains of Pseudomonas genomospecies FP3 have LPS patterns that are different from those of strains of Pseudomonas genomospecies FP1 and FP2.

Pseudomonas genomospecies FP1 and FP2 are related to each other (levels of DNA relatedness, 40 to $60 \%$ ) but are weakly related to Pseudomonas genomospecies FP3 (levels of 
DNA relatedness, 18 to $26 \%$ [as determined by the $\mathrm{S} 1$ nuclease-trichloroacetic acid method]).

The DNA G+C content is $59.2 \mathrm{~mol} \%$ for Pseudomonas genomospecies FP1 and FP2 and 60.2 mol\% for Pseudomonas genomospecies FP3 (as determined by the thermal denaturation method). The type strains are strain CFBP 10529 for Pseudomonas genomospecies FP1, strain CFBP 10530 for Pseudomonas genomospecies FP2, and strain CFBP 10569 for Pseudomonas genomospecies FP3. These three type strains were isolated from tomatoes with symptoms of pith necrosis in France from 1980 to 1983 . The type strains and additional strains have been deposited in the Collection Française de Bactéries Phytopathogènes (CFBP), Angers, France.

\section{ACKNOWLEDGMENTS}

We thank S. Köhn, K. Naumann, E. Griesbach, M. Scortichini, H. Kuwata, K. Oikawa, K. Olsson, P. Persson, J. Vogelsanger, R. Grimm, W. P. Bond, L. L. Black, J. B. Jones, F. L. Lukezic, and B. Rat for providing bacterial isolates, S. Belouin for technical assistance, J. Corzo for expert advice on LPS polyacrylamide gel electrophoresis, $\mathrm{F}$. Garcia for collaboration in the study of fatty acid profiles, A. Huard for designing the dendrogram, and J. Hartman for reading the manuscript.

\section{REFERENCES}

1. Alarcon, B., M. M. Lopez, M. Cambra, M. T. Gorris, and J. Guerri. 1990. Differentiation of Erwinia carotovora subsp. carotovora and Erwinia carotovora subsp. atroseptica isolated from potato by Western blot and subsequent indirect ELISA. J. Appl. Bacteriol. 69:17-24.

2. Alippi, A. M., L. Ronco, and H. E. Alippi. 1993. Tomato pith necrosis caused by Pseudomonas comugata in Argentina. Plant Dis. 77:428.

3. Alivizatos, A. S. 1984. Aetiology of tomato pith necrosis in Greece, p. 55-57. In Proceedings of the 2nd Working Group on Pseudomonas syringae Pathovars, Sounion. Hellenic Phytopathological Society, Athens, Greece.

4. Ayers, S. H., P. Rupp, and W. T. Johnson. 1919. A study of alkali-forming bacteria in milk. Bulletin no. 782. U. S. Department of Agriculture, Washington, D.C

5. Brenner, D. J., A. C. McWorter, J. K. Leete Knutson, and A. G. Steigerwalt. 1982. Escherichia vulneris: a new species of Enterobacteriaceae associated with human wounds. J. Clin. Microbiol. 15:1133-1140.

6. Catara, V. 1994. Ph.D. thesis. University of Catania, Catania, Italy.

7. Catara, V., and G. Albense. 1993. La necrosi del midollo del pomodoro in Sicilia. Inf. Fitopatol. 9:42-44.

8. Clark, R. G., and D. R. Watson. 1986. New plant disease record in New Zealand: tomato pith necrosis caused by Pseudomonas comugata. N. Z. J. Agric. Res. 29:105-109.

9. Crosa, J. M., D. J. Brenner, and S. Falkow. 1973. Use of a single-strandspecific nuclease for analysis of bacterial and plasmid deoxyribonucleic acid homo- and heteroduplexes. J. Bacteriol. 115:904-911.

10. Descamps, $\mathbf{P}$., and $\mathbf{M}$. Véron. 1981. Une méthode de choix des caractères d'identification basée sur le théorème de Bayes et la mesure de l'information. Ann. Inst. Pasteur/Microbicl. (Paris) 132B:157-170.

11. De Vos, P., A. Van Landshoot, P. Segers, R. Tytgat, M. Gillis, M. Bauwens, R. Rossau, M. Goor, B. Pot, K. Kersters, P. Lizzaraga, and J. De Ley. 1989. Genotypic relationship and taxonomic localization of unclassified Pseudomonas and Pseudomonas-like strains by deoxyribonucleic acid-ribosomal ribonucleic acid hybridization. Int. J. Syst. Bacteriol. 39:35-49.

12. De Vos, P., M. Goor, M. Gillis, and J. De Ley. 1985. Ribosomal ribonucleic acid cistron similarities of phytopathogenic Pseudomonas species. Int. J. Syst. Bacteriol. 35:169-184.

13. Dhanvantari, B. N. 1990 . Stem necrosis of greenhouse tomato caused by a novel Pseudomonas sp. Plant Dis. 74:124-127.

14. Fiori, M. 1992. A new bacterial disease of Chrysanthemum: a stem rot by Pseudomonas corrugata Roberts et Scarlett. Phytopathol. Mediterr. 31:110114.

15. Fiori, M., P. Corda, and C. Carta. 1983. Pseudomonas corrugata Roberts et Scarlett agente della necrosi del midollo dei pomodoro (Licopersicon esculentum Mill). Riv. Patol. Veg. 19:21-27.

16. Grimont, P. A. D., M. Y. Popoff, F. Grimont, C. Coynault, and M. Lemelin. 1980. Reproductibility and correlation study of three deoxynucleic acid hybridization procedures. Curr. Microbiol. 4:325-330.

17. Hildebrand, D. C. 1971 . Pectate and pectine gels for differentiation of Pseudomonas sp. and other bacterial plant pathogens. Phytopathology 61: 1430-1436.

18. Hitchcock, P. J., and T. M. Brown. 1983. Morphological heterogeneity among Salmonella lipopolysaccharide chemotypes in silver-stained polyacrylamide gels. J. Bacteriol. 154:269-277.
19. Hu, F. P., J. M. Young, and C. M. Triggs. 1991. Numerical analysis and determinative tests for nonfluorescent plant-pathogenic Pseudomonas spp. and genomic analysis and reclassification of species related to Pseudomonas avenae Manns 1909. Int. J. Syst. Bacteriol. 41:516-525.

20. Johnson, J. L. 1973. Use of nucleic acid homologies in the taxonomy of anaerobic bacteria. Int. J. Syst. Bacteriol. 23:308-315.

21. Jones, J. B., J. P. Jones, R. E. Stall, and J. W. Miller. 1983. Occurrence of stem necrosis on field-grown tomatoes incited by Pseudomonas comugata in Florida. Plant Dis. 67:425-426.

22. Laemmli, U. K. 1970 . Cleavage of structural proteins during the assembly of the head of bacteriophage T4. Nature (London) 227:680-685.

23. Lai, M., D. C. Opgenorth, and J. B. White. 1983. Occurrence of Pseudomonas corrugata on tomato in California. Plant Dis. 67:110-112.

24. Leliott, R. A., E. Billing, and A. C. Hayward. 1966. A determinative scheme for the fluorescent plant pathogenic pseudomonads. J. Appl. Bacteriol. 29: 470-489.

25. Lopez, M. M., F. Siverio, M. R. Albiach, F. Garcia, and R. Rodriguez. 1994. Characterization of Spanish isolates of Pseudomonas comugata from tomato and pepper. Plant Pathol. 43:80-90.

26. Lukezic, F. L. 1979. Pseudomonas comugata, a pathogen of tomato isolated from symptomless alfalfa roots. Phytopathology 69:27-31.

27. Marmur, J., and P. Doty. 1962. Determination of the base composition of deoxyribonucleic acid from its thermal denaturation temperature. J. Mol. Biol. 5:109-118.

28. Miller, L. T., and T. Berger. 1985. Bacterial identification by gas chromatography of whole cell fatty acids. Hewlett-Packard Application Note 228241. Hewlett-Packard Co., Palo Alto, Calif.

29. Ostle, A., and J. G. Holt. 1975. Nile Blue A as a fluorescent stain for poly- $\beta$-hydroxybutyrate. Appl. Environ. Microbiol. 44:238-240.

30. Owen, R. J., and S. P. Lapage. 1976. The thermal denaturation of partly purified bacterial deoxyribonucleic acid and its taxonomic implications. J. Appl. Bacteriol. 41:335-340.

31. Palleroni, N. J. 1984. Genus I. Pseudomonas Migula 1894, p. 141-199. In N. R. Krieg and J. G. Holt (ed.), Bergey's manual of systematic bacteriology, vol. 1. The Williams and Wilkins Co., Baltimore, Md.

32. Paulin, J. P. 1979. Nécrose de la moëlle ou moëlle noire, p. 505. In Les maladies des plantes. Association de Coordination Technique Agricole Paris, France.

33. Prunier, J. P., and P. Kaiser. 1964. Etude de l'activité pectinolytique chez des bactéries phytopathogènes et saprophytes des plantes. I. Recherche des enzymes pectinolytiques. Ann. Epiphyt. (Paris) 15:205-209.

34. Rhodes, M. E. 1958. The cytology of Pseudomonas spp. as revealed by silver-plating staining method. J. Gen. Microbiol. 18:639-648.

35. Scarlett, C. M., J. T. Fletcher, P. Roberts, and R. A. Leliott. 1978. Tomato pith necrosis by Pseudomonas corrugata n. sp. Ann. Appl. Biol. 88:105-114.

36. Schaad, N. W. 1988. Laboratory guide for identification of plant pathogenic bacteria. American Phytopathological Society, St. Paul, Minn.

37. Scortichini, M. 1989. Occurrence in soil and primary infections of Pseudomonas corrugata Roberts and Scarlett. J. Phytopathol. 125:33-40.

38. Siverio, F. 1994. Ph.D. thesis. University of La Laguna, Tenerife, Spain.

39. Siverio, F. M. Cambra, M. T. Gorris, J. Corzo, and M. M. Lopez. 1993. Lipopolysaccharides as determinants of serological variability in Pseudomonas corrugata. Appl. Environ. Microbiol. 59:1805-1812.

40. Siverio, F., A. A. Carbonell, F. Garcia, and M. M. Lopez. 1996. Characteristics of the whole cell fatty acid profiles of Pseudomonas corrugata. Eur. J. Plant Pathol. 102:519-526.

41. Sneath, P. H. A., and R. R. Sokal. 1973. Numerical taxonomy. The principles and practice of numerical classification. W. H. Freeman, San Francisco, Calif.

42. Stead, D. E. 1992. Grouping of plant-pathogenic and some other Pseudomonas spp. by using cellular fatty acid profiles. Int. J. Syst. Bacteriol. 42:281-295.

43. Stead, D. E., J. E. Sellwood, J. Wilson, and I. Viney. 1992. Evaluation of commercial microbial identification system based on fatty acid profiles for rapid, accurate identification of plant pathogenic bacteria. J. Appl. Bacteriol. 72:315-321.

44. Tsai, C. M., and C. E. Frasch. 1982. A sensitive silver stain for detecting lipopolysaccharide in polyacrylamide gels. Anal. Biochem. 119:115-119.

45. Van Outryve, M. F., M. T. Cerez, M. De Cleene, J. Swings, and T. W. Mew. 1992. Pathogenic pseudomonads associated with steath rot and grain discoloration of rice, p. P1/A5. In Abstracts of the 8th International Conference on Plant Pathogenic Bacteria, Versailles. INRA/ORSTOM Editions, Paris, France.

46. Wayne, L. G., D. J. Brenner, R. R. Colwell, P. A. D. Grimont, O. Kandler, M. I. Krichevsky, L. H. Moore, W. E. C. Moore, R. G. E. Murray, E. Stackebrandt, M. P. Starr, and H. G. Trüper. 1987. Report of the Ad Hoc Committee on Reconciliation of Approaches to Bacterial Systematics. Int. J. Syst. Bacteriol. 37:463-464.

47. Wilkie, J. P., and D. W. Dye. 1974. Pseudomonas cichorii causing tomato and celery diseases in New Zealand. N. Z. J. Agric. Res. 17:123-130.

48. Young, J. M., Y. Takikawa, L. Gardan, and D. E. Stead. 1992. Changing concepts in the taxonomy of plant pathogenic bacteria. Annu. Rev. Phytopathol. 30:67-105. 